\title{
Gridded emissions of air pollutants for the period 1970-2012 within EDGAR v4.3.2
}

\author{
Monica Crippa $^{1}$, Diego Guizzardi ${ }^{2}$, Marilena Muntean ${ }^{1}$, Edwin Schaaf $^{1}$, Frank Dentener ${ }^{1}$, \\ John A. van Aardenne ${ }^{3}$, Suvi Monni ${ }^{4}$, Ulrike Doering ${ }^{5}$, Jos G. J. Olivier ${ }^{6}$, Valerio Pagliari ${ }^{1}$, and \\ Greet Janssens-Maenhout ${ }^{1}$ \\ ${ }^{1}$ European Commission, Joint Research Centre (JRC), Via E. Fermi 2749, 21027 Ispra (VA), Italy \\ ${ }^{2}$ Didesk Informatica, Verbania, Italy \\ ${ }^{3}$ European Environment Agency, Copenhagen, Denmark \\ ${ }^{4}$ Benviroc Ltd., Helsinki, Finland \\ ${ }^{5}$ German Environment Agency, Dessau, Germany \\ ${ }^{6}$ PBL Netherlands Environmental Assessment Bureau, Den Hague, the Netherlands
}

Correspondence: Monica Crippa (monica.crippa@ec.europa.eu)

Received: 4 March 2018 - Discussion started: 9 April 2018

Revised: 8 August 2018 - Accepted: 18 September 2018 - Published: 26 October 2018

\begin{abstract}
The new version of the Emissions Database for Global Atmospheric Research (EDGAR v4.3.2) compiles gaseous and particulate air pollutant emissions, making use of the same anthropogenic sectors, time period (1970-2012), and international activity data that is used for estimating GHG emissions, as described in a companion paper (Janssens-Maenhout et al., 2017). All human activities, except large scale biomass burning and land use, land-use change, and forestry are included in the emissions calculation. The bottom-up compilation methodology of sector-specific emissions was applied consistently for all world countries, providing methodological transparency and comparability between countries. In addition to the activity data used to estimate GHG emissions, air pollutant emissions are determined by the process technology and end-of-pipe emission reduction abatements. Region-specific emission factors and abatement measures were selected from recent available scientific literature and reports. Compared to previous versions of EDGAR, the EDGAR v4.3.2 dataset covers all gaseous and particulate air pollutants, has extended time series (1970-2012), and has been evaluated with quality control and quality assurance (QC and QA) procedures both for the emission time series (e.g. particulate matter - PM - mass balance, gap-filling for missing data, the split-up of countries over time, few updates in the emission factors, etc.) and grid maps (full coverage of the world, complete mapping of EDGAR emissions with sector-specific proxies, etc.). This publication focuses on the gaseous air pollutants of $\mathrm{CO}, \mathrm{NO}_{x}, \mathrm{SO}_{2}$, total non-methane volatile organic compounds (NMVOCs), $\mathrm{NH}_{3}$, and the aerosols $\mathrm{PM}_{10}$, $\mathrm{PM}_{2.5}$, black carbon (BC), and organic carbon (OC). Considering the 1970-2012 time period, global emissions of $\mathrm{SO}_{2}$ increased from 99 to $103 \mathrm{Mt}$, CO from 441 to $562 \mathrm{Mt}, \mathrm{NO}_{x}$ from 68 to $122 \mathrm{Mt}$, NMVOC from 119 to $170 \mathrm{Mt}, \mathrm{NH}_{3}$ from 25 to $59 \mathrm{Mt}, \mathrm{PM}_{10}$ from 37 to $65 \mathrm{Mt}, \mathrm{PM}_{2.5}$ from 24 to $41 \mathrm{Mt}, \mathrm{BC}$ from 2.7 to $4.5 \mathrm{Mt}$, and OC from 9 to $11 \mathrm{Mt}$. We present the country-specific emission totals and analyze the larger emitting countries (including the European Union) to provide insights on major sector contributions. In addition, per capita and per GDP emissions and implied emission factors - the apparent emissions per unit of production or energy consumption - are presented. We find that the implied emission factors (EFs) are higher for low-income countries compared to high-income countries, but in both cases decrease from 1970 to 2012. The comparison with other global inventories, such as the Hemispheric Transport of Air Pollution Inventory (HTAP v2.2) and the Community Emission Data System (CEDS), reveals insights on the uncertainties as well as the impact of data revisions (e.g. activity data, emission factors, etc.). As an additional metric, we analyze the emission ratios of some pollutants to $\mathrm{CO}_{2}$ (e.g. $\mathrm{CO} / \mathrm{CO}_{2}, \mathrm{NO}_{x} / \mathrm{CO}_{2}, \mathrm{NO}_{x} / \mathrm{CO}$, and $\mathrm{SO}_{2} / \mathrm{CO}_{2}$ ) by sector, region, and time to identify any decoupling of air pollutant emissions from energy production activities and to demonstrate the potential
\end{abstract}


of such ratios to compare to satellite-derived emission data. Gridded emissions are also made available for the 1970-2012 historic time series, disaggregated for 26 anthropogenic sectors using updated spatial proxies. The analysis of the evolution of hot spots over time allowed us to identify areas with growing emissions and where emissions should be constrained to improve global air quality (e.g. China, India, the Middle East, and some South American countries are often characterized by high emitting areas that are changing rapidly compared to Europe or the USA, where stable or decreasing emissions are evaluated). Sector- and component-specific contributions to grid-cell emissions may help the modelling and satellite communities to disaggregate atmospheric column amounts and concentrations into main emitting sectors. This work addresses not only the emission inventory and modelling communities, but also aims to broaden the usefulness of information available in a global emission inventory such as EDGAR to also include the measurement community. Data are publicly available online through the EDGAR website http://edgar.jrc.ec.europa.eu/overview.php?v=432_AP and registered under https://doi.org/10.2904/JRC_DATASET_EDGAR.

\section{Introduction}

Air pollutant emissions represent a major concern for air quality (Monks et al., 2009), climate impacts (Anenmber et al., 2012; IPCC, 2013), health (WHO, 2016), environmental effects (Van Dingenen et al., 2009), and visibility (Wang et al., 2012). The first international treaty dealing with air quality was the UNECE CLRTAP (Convention on Long-Range Transboundary Air Pollution of the United Nations Economic Commission for Europe), which entered into force in 1979 with a focus on global, regional, and local air quality issues and acid rain (https://www.unece.org, last access: April 2018). Atmospheric pollutants can be emitted as gaseous compounds, e.g. $\mathrm{SO}_{2}$ (sulfur dioxide), $\mathrm{NO}_{x}$ (nitrogen oxides), $\mathrm{CO}$ (carbon monoxide), NMVOCs (nonmethane volatile organic compounds), $\mathrm{NH}_{3}$ (ammonia), etc., or as particles with different sizes and composition, e.g. particulate matter with a diameter of less than 10, 2.5, and $1 \mu \mathrm{m}\left(\mathrm{PM}_{10}, \mathrm{PM}_{2.5}\right.$, and $\mathrm{PM}_{1}$, respectively), black carbon (BC), and organic carbon (OC). These pollutants can be directly injected into the atmosphere by anthropogenic or natural sources (primary emissions), or they can form through secondary chemical-physical processes (secondary components). The aforementioned gaseous compounds consist of primary pollutants together with primarily emitted particulate matter, while the secondary components mainly include secondary organic (SOA) and inorganic aerosols (e.g. ammonium nitrates and ammonium sulfates) and ozone $\left(\mathrm{O}_{3}\right)$, as reported by Seinfeld and Pandis (2006). In addition, air pollutants can be transported far away from source regions, depending on the pollutants' reactivity as well as meteorological dynamics (Maas and Grennfelt, 2016). Air pollution sources impact air quality at local, regional, and global scales (HTAP, 2010). Moreover, despite regional variations, air pollution is a ubiquitous problem with, to a large extent, common solutions between regions. To tackle these regional and global aspects, global emission inventories coupled with chemical transport models (CTMs) are useful tools, complementing air pollution measurements that provide in- formation on local and regional air quality impacts. In the recent years several global emission inventories have been developed, such as the one of Lamarque et al. (2010), the MACCity by Granier et al. (2011), the one documented by Klimont et al. (2013) for $\mathrm{SO}_{2}$, the Hemispheric Transport of Air Pollution Inventory (HTAP v2.2) by JanssensMaenhout et al. (2015), the Community Emission Data System (CEDS) by Hoesly et al. (2018), and the inventory based on Greenhouse Gas and Air Pollution Interactions and Synergies (GAINS), and ECLIPSEV5a by Klimont et al. (2017) for particulate matter. The EDGAR database (Emissions Database for Global Atmospheric Research) is a bottom-up global database providing historic emission time series and grid maps for all countries from 1970 until the present for both air pollutants and greenhouse gases calculated in a consistent and transparent way, therefore allowing comparability amongst countries. The work presented here is complementary to the study on the greenhouse gases by JanssensMaenhout et al. (2017) and aims at documenting the new EDGAR v4.3.2 version with a focus on the gaseous air pollutants $\left(\mathrm{SO}_{2}, \mathrm{NO}_{x}, \mathrm{CO}, \mathrm{NMVOC}\right.$, and $\left.\mathrm{NH}_{3}\right)$ and on the aerosols including only primary particles $\left(\mathrm{PM}_{10}, \mathrm{PM}_{2.5}\right.$, and their organic components $\mathrm{BC}$ and $\mathrm{OC}$ ). The purpose of this publication is to document the methodology and the data availability of the EDGAR v4.3.2 air pollutant release. A huge amount of information is included in this release, covering 42 years of data, 26 aggregated emission sectors, 226 countries, and 9 substances. In addition, emissions are represented both as time series and emission grid maps. A detailed analysis of all driving data, trends, and peculiarities of this dataset is beyond the scope of this work. Instead we focus on presenting the key outcomes of regional and global emissions and their temporal trends. We also provide an analysis of some key features of the large amount of information available at the grid-cell level, such as the sector's relative contribution or the emission change over time of the different pollutants and sectors, which warrant further analysis by modelling and satellite communities. In addition we examine the per capita and per GDP emissions, implied emission 
factors, etc., for countries and sectors in order to analyze regional differences in equity and efficiency. In Sect. 2 we describe the EDGAR methodology in addition to the extensive documentation provided in the companion paper on GHGs (Janssens-Maenhout et al., 2017); then in Sect. 3, we show the global trends and the comparison with other global inventories, such as HTAP v2.2 and CEDS, revealing insights on the causes of uncertainty and the impact of data revisions. Compared to the previous EDGAR v4.3.1 release, the current EDGAR v4.3.2 dataset covers a longer time series (1970-2012 vs. 1970-2010) and experiences some updates in the activity data, emission factors, full quality assurance, and quality check procedure implementation, but it covers the same pollutants and relies on the same proxy data as used in v4.3.1 (Crippa et al., 2016a). In Sect. 4 we present implied emission factors (apparent EFs per unit of production or energy consumption), per capita and per GDP emissions, and country-specific emission totals amongst world countries. We also analyze the variations of several large emitting countries and the EU in more depth to provide insights on the main sectors contributing to the emissions of each pollutant. Finally, in Sects. 5 and 6 we discuss the sector-specific relative composition at the grid-cell level and analyze the emission ratios of $\mathrm{CO} / \mathrm{CO}_{2}, \mathrm{NO}_{x} / \mathrm{CO}_{2}$, and $\mathrm{SO}_{2} / \mathrm{CO}_{2}$ by sector, region, and time, providing useful information for the measurement community. In addition we provide sectorspecific emission shares calculated at the grid-cell level with $0.1^{\circ} \times 0.1^{\circ}$ resolution, allowing the retrieval of sectorial information from the total column measurements of each pollutant. Data are presented online for each source category with annual and monthly global-emission grid maps at $0.1^{\circ} \times 0.1^{\circ}$ resolution. All data can be freely accessed via the EDGAR website (http://edgar.jrc.ec.europa.eu/overview.php?v=432_ AP, last access: October 2018), and they are registered under DOI https://doi.org/10.2904/JRC_DATASET_EDGAR.

\section{Methods}

\subsection{Methodology of the bottom-up emission inventory compilation and distribution}

The EDGAR v4.3.2 air pollutant dataset incorporates a full differentiation of emission processes with technologyspecific emission factors and additional end-of-pipe abatement measures, which are more relevant for air pollutants than for greenhouse gases. The definition of the anthropogenic emission sectors was kept identical to the ones used for the EDGAR v4.3.2 GHG dataset (Janssens-Maenhout et al., 2017) that were based on the Intergovernmental Panel on Climate Change (IPCC,1996) guidelines for which the conversion to the Selected Nomenclature for Air Pollution (SNAP) categories used by TFEIP (Task Force on Emission Inventories and Projections) and the parties of the Convention on Long-range Transboundary Air Pollution (CLRTAP) are unambiguously given ${ }^{1}$. The same time period and the same international activity data as the GHGs are also used for consistency. The equation for GHG emissions is modified by a factor $f_{x}$ (varying between 0 and 1 ) that specifies the components of each pollutant, e.g. gaseous NMVOCs (Huang et al., 2017; http://edgar.jrc.ec.europa.eu/overview.php?v=432 VOC_spec, last access: October 2018), particulate OC, $\mathrm{NO}_{x}$ (which can be assumed to be composed of $90 \% \mathrm{NO}$ and $10 \%$ $\mathrm{NO}_{2}$ for primary emissions), etc., and may be represented by the following:

$$
\begin{aligned}
\operatorname{EM}_{i}(C, t, x)= & \sum_{j, k}\left[\operatorname{AD}_{i}(C, t) \cdot \mathrm{TECH}_{i, j}(C, t)\right. \\
& \cdot \operatorname{EOP}_{i, j, k}(C, t) \cdot \mathrm{EF}_{i, j}(C, t, x) \\
& \left.\cdot\left(1-\operatorname{RED}_{i, j, k}(C, t, x)\right) \cdot f_{x}\right],
\end{aligned}
$$

with emissions (EM) from a given sector $i$ in a country $C$ accumulated during a year $t$ for a chemical compound $x$, with the country-specific activity data (AD) quantifying the human activity for sector $i$, the mix of $j$ technologies (TECH, varying between 0 and 1), the mix of $k$ (end-ofpipe) abatement measures (EOP, varying between 0 and 1) installed with a share $k$ for each technology $j$, and the uncontrolled emission factor (EF) for each sector $i$ and technology $j$ with relative reduction (RED) by abatement measure $k$. As discussed in the next section, the uncontrolled emission factors and abatement measures were applied at the Tier 1-3 levels, depending on the anthropogenic sector. In our paper we focus on total NMVOC emissions, however, region- and sector-specific NMVOC speciation profiles have been developed and applied to the EDGAR database with the same sector resolution as the total NMVOC, briefly described below. The complete documentation on the speciation profiles and on the methodology used can be found in Huang et al. (2017), while speciated NMVOC emissions for EDGARv4.3.2 are available at the following website: http:// edgar.jrc.ec.europa.eu/overview.php?v=432_VOC_spec (last access: October 2018). Based on a comprehensive literature review, speciation profiles from regional measurements and databases are applied to split the EDGAR total NMVOC emissions into individual species, which are then lumped into 25 species groups as proposed by the Global Emissions InitiAtive (GEIA). NMVOC speciation profiles collected from the different databases and publications were then mapped to all EDGAR processes. A quality assessment by region, emission source, and NMVOC species is performed focusing on Europe, North America, and China. In addition the comparison between the EDGAR speciated database and the RETRO (Schultz et al., 2007) data is conducted, showing a general good agreement of the two datasets for Europe and the USA, while for China, higher contents of chlorinated hydrocarbon emissions from fuel extraction and industrial and power gen-

\footnotetext{
${ }^{1}$ http://www.ceip.at/fileadmin/inhalte/emep/pdf/NFR09_ SNAP_GNFR.pdf; last access: March 2018
} 
eration sectors are found from the EDGAR dataset, consistent with speciation profiles of coal combustion sources collected from Chinese local studies (Cai et al., 2010; Liu et al., 2008; Wei et al., 2012).

Most emissions are computed using international activity data from the International Environmental Agency (IEA, 2014), Food and Agriculture Organization Corporate Statistical Database (FAOSTAT, 2016), Food and Agriculture Organization of the United Nations (FAO, 2016), U.S. Geological Survey (USGS, 2014), United Nations Statistics (UN STATS, 2014), and the United Nations Framework Convention on Climate Change (UNFCCC, 2014), similar to the GHG emission dataset described by Janssens-Maenhout et al. (2017) and references therein. These data are complemented with national or regional information on the technology mixes and end-of-pipe measures. The details of EDGAR v4.3.2 activity data sources (i.e. the population, energy, fossil fuel production, industrial processes, solvents, agricultural, solid waste product, waste water, and other historical statistics) are given in Sect. 2.3 of Janssens-Maenhout et al. (2017). While EFs were indeed determined mostly in North America and Europe, they pertain to a range of technologies. Emissions in developing countries are often higher than in industrialized countries, because some of the technologies they use now were only common in North America and Europe until some decades ago. The main uncertainty therefore is to know which technologies are used in developing countries and to what extent older technologies are replaced by newer ones. In some cases, installed equipment may not be properly operating or might be defective, which may also lead to higher emissions. In this study no uncertainty analysis evaluating the non-representativeness of emission factors from one region to another has been performed. The emission factors used in EDGAR are mainly based on the EMEP/EEA (2013) guidebook and partly on the latest available scientific knowledge (EMEP/EEA, 2016; see guidebook). When information on EFs is missing or very uncertain (e.g. for African countries), default emission factors are considered to keep the consistency and comparability of the emissions among countries. For Latin America, a specific study has been performed to include region-specific EFs for the road transport sector based on the work of D'Angiola et al. (2010) and Schifter et al. (2005). Such emission factors have also been applied in countries with emerging economies. More details on the road transport sector can be found in Crippa et al. (2016b). Emission inventories can also be updated, implementing results provided by inverse modelling. However, the current version of the EDGAR database takes a conservative approach in using such information for the air pollutants, since a mismatch of observed concentrations and resulting "updated" inverse-modelling-derived emissions may often be attributed to multiple sources of uncertainties in emissions, models, and observations. If not based on solid and wellevaluated information, emission data might be modified with incorrect or inconsistent information; therefore we prefer to present our best available information on activity data and EFs without correction. One example where compelling results from inverse modelling have been used is the update of $\mathrm{CH}_{4}$ emission factors of EDGARv4.3.2, which, for instance, have consistently indicated lower emissions from coal mining than those assumed in EDGAR, as documented in Janssens-Maenhout et al. (2017). For the spatial and temporal distribution of the sector-specific emission totals of a substance $x$ for a country $C$ in the year $t$ (monthly) and space (on $0.1^{\circ} \times 0.1^{\circ}$ grids, defined with bottom-left corner for each cell), the same allocation algorithm and proxy datasets used for the GHG dataset of Janssens-Maenhout et al. (2017) are applied (refer to Sect. 2.4 and 2.5 of Janssens-Maenhout et al., 2017). The temporal variability of human emissions is an important factor to be modelled by a global emission inventory; therefore, the EDGAR database provides both annual and monthly emissions for each sector. The EDGAR v4.3.2 monthly emissions available on the EDGAR website (http:// edgar.jrc.ec.europa.eu/overview.php?v=432_AP, last access: October 2018) are computed using the EDGAR temporal profiles described in Table S4a by Janssens-Maenhout et al. (2017). However, we point to a recent study that has been performed in order to improve the modelling of the seasonal patterns of air pollutants and GHG emissions in the EDGAR database. This approach, as documented by Huang et al. (2018), will be applied to the EDGAR forthcoming version of the EDGAR emission database (i.e. after v4.3.2). We report Table S4a and b of the aforementioned paper in Tables S6a and b of the Supplement as references for the geospatial proxy data and temporal profiles applied to the EDGAR v4.3.2 data.

The EDGAR database provides emissions disaggregated for different heights only for the aviation sector (both domestic and international). Aviation emissions are evaluated for three different heights corresponding to different flight phases: the landing and take-off estimated at the height between 0 and $1 \mathrm{~km}$ altitude, climbing and descent estimated at the height between 1 and $9 \mathrm{~km}$ altitude, and the cruise flight estimated at the height between 9 and $13 \mathrm{~km}$ altitude. In addition, supersonic flights emissions are estimated to happen at heights above $13 \mathrm{~km}$ altitude, although they are a minor source of emissions. No military flights are taken into account. For the other sectors, the EDGAR database does not provide information about the emission heights, although it is a determining factor together with plume rise for emissions emitted at stacks for plume and global transport modelling. In this study we do not address this aspect, however, we can provide the following recommendations. For a global dataset of air pollution, precise stack heights cannot be provided due to the lack of information, but a classification of each emission sector into ground-level or stackheight emissions can be assumed, as done in former publications using the EDGAR datasets (UNEP/WMO, 2011). Anthropogenic emissions that are classified as areal emissions (e.g. transportation, agriculture, and residential) are mostly 
happening close to the ground, and modellers can assume an emission height below $150 \mathrm{~m}$, while point-source emissions are mostly from the stacks of power plants and industrial facilities in general, occurring above $150 \mathrm{~m}$. However, it should be noted that emission heights from smaller-scale industries in developing countries may be at lower heights. In the following, we will describe our results looking at the aggregated sectors of energy (power generation sector), industry (including industrial combustion, the production of chemicals, non-metallic minerals, non-ferrous metals, iron and steel, solvents, food, paper, the non-energy use of fuels, fuel production and transformation, refineries, and fossil fuel fires), transport (including both road and non-road transport), residential (including both domestic combustion and waste disposal), and agriculture (including agricultural soils, agricultural waste burning, and manure management). In order not to count agricultural waste burning emissions twice, end users of the EDGAR database that complement it with open biomass burning emission inventories (e.g. GFED, FINN, etc.) to cover emissions from fires should be aware of what is included in both databases.

\subsection{Data sources to model the technology-based emission processes}

The emissions cover all known activities except large-scale biomass burning and activities of land use, land-use change, and forestry from 1970-2012. The bottom-up compilation of sector-specific emissions was applied consistently for all world countries, providing methodological transparency and comparability amongst countries. In addition to the activity data, the air pollutant emissions are determined by the technology and end-of-pipe abatements (contrary to GHGs). Region-specific emission factors and abatement measures were selected from the latest available literature and available recent knowledge. Section S4 of the Supplement provides an overview of the technologies and abatements implemented in EDGAR v4.3.2 for all sectors. Combustion technologies, combustion temperatures, and the end-of-pipe measures determine the amount of air pollutants emitted and are modelled separately for stationary and mobile combustion sources. Under the latter, the road transport sector is modelled with pre-EURO to EURO 5 standards, US Tier 1 to Tier 3 standards and is described in detail in Crippa et al. (2016b), whereas the aviation sector is modelled following Eyers et al. (2005) and the shipping sector follows Dalsøren et al. (2009).

The stationary combustion sector includes smalland medium-sized boilers for gas and liquid fuels, internal combustion engines, gas turbines, fluidized bed, grate firing, and pulverized coal dry bottom boilers. Country-specific shares of the technologies are taken from the UDI Platts Power Plant Database (2008; https://www.spglobal.com/platts/en/products-services/ electric-power/world-electric-power-plants-database, last access: October 2018) and updated with region specific information from the EPRTR v4.2 database for Europe, with information from Zhao et al. (2012) for China, as documented in Muntean et al. (2018). Further updates of the technologies used in this sector are foreseen for the next releases of the EDGAR database. The end-ofpipe measures are from the International Energy Agency (IEA) Clean Coal Centre (IEA Clean coal power DB, http://www.iea-coal.co.uk/, last access: October 2018) and are updated with the European Pollutant and Transfer Register (EPRTR) (2012) for Europe, the Environmental Protection Agency (US EPA, 2014) for the USA, and Zhao et al. (2012) for China; countries falling short in data, the technology mixes, and end-of-pipe measures are estimated using neighbouring countries or regions as proxies. For the USA, the EU, and China, air quality policies are assumed to kick in with immediate and full effectiveness, so the possible phased implementation imposed by these policies in which regulations have to be implemented is not considered in our database. In Europe, policies include, in particular, not only the National Emission Ceiling directive (2001/81/EC) but also the earlier air quality directives (80/779/EEC, 85/203/EEC), the Air Quality Framework Directive (96/62/EC), the Ambient Air Directive (2000/69/EC for CO), the Ambient Air Quality Directive (2008/50/EC), which was mainly for PM, and the Integrated Pollution Prevention and Control (IPPC) Directive (2008/1/EC). The 2016 revision of the National Emission Ceilings Directive, effective from 2020 onwards, falls outside of the considered time period. For the energy sector, end-of-pipe measures are applied for particulate matter components, specifically cyclones (with $90 \%$ abatement for $\mathrm{PM}_{10}$ and $0 \%$ for $\mathrm{PM}_{2.5}$ and its carbonaceous components), combinations of electrostatic precipitators, and fabric filters (with $99.95 \%$ abatement for $\mathrm{PM}_{10}$ and between $98.3 \%$ and $99.6 \%$ abatement for $\mathrm{PM}_{2.5}$ and its components). The aforementioned abatements are applied to all fuels, particularly the coal-related ones. $\mathrm{SO}_{x}$ reduction measures of $50 \%$ by non-regenerative-dry flume gas desulfurization (dry FGD) and the $\mathrm{SO}_{x}$ reduction of $90 \%$ by non-regenerative semidry, non-regenerative wet FGD, and regenerative $\mathrm{SO}_{x} \mathrm{NO}_{x}$ are also included. Concerning $\mathrm{NO}_{x}$ reduction measures, a $30 \%$ reduction is assumed for low- $\mathrm{NO}_{x}$ burners, low excess air, air staging in furnaces, flue gas recirculation (in the furnace), reduced air preheat, and fuel stages; abatements of $60 \%$ for selective catalytic reduction and $90 \%$ for selective catalytic reduction combined with combustion modification are also assumed. The $\mathrm{NO}_{x}$ reduction from $30 \%$ to $90 \%$ is obtained by selective non-catalytic reduction and of $90 \%$ by $\mathrm{SO}_{x} \mathrm{NO}_{x}$ combined measures. For these point sources, data from the EPRTR v4.2 have been consulted as well as the reported specifications under the large combustion directive.

For the transport sector, a description is given by Crippa et al. (2016b). We did not consider cold starts, super-emitting vehicles, the resuspension of road dust, or brake and tyre 
wear. In addition, we used the recommended $\mathrm{EF}$ for $\mathrm{NO}_{x}$ from test benches instead of from real driving mode measurements. This explains the expected underestimation (with a factor of almost 2) of the $\mathrm{PM}_{2.5}$ emissions and of the $\mathrm{NO}_{x}$ emissions. For the residential sector, we used generic data of few national statistics on the combustion technology used in the given country, for example, which was also inherited for neighbouring countries in case data were missing.

The data sources for the management systems applied for coal mining (surface or underground, with or without recovery), the technologies for iron and steel production (open hearth furnace, blast oxygen furnace, and electric arc furnace), technologies for the aluminium smelters (Prebake or Soederberg types), high- to low-pressure technologies for the nitric acid production, and the different sewing types for domestic and industrial waste-water treatment are described in the v4.3.2 GHG companion paper of Janssens-Maenhout et al. (2017). That paper also provides a description of activity data relevant to agricultural emissions, namely the manure management systems (burned for fuel, dropped in pastures, ranges, or paddock, digesters, dry lots, daily spreads, lagoons, liquid slurry, pits, solid storage, or others) and the four ecology types for rice cultivation (rainfed, irrigated, deep water, and upland), as these also determine the $\mathrm{CH}_{4}$ emission factors.

\section{Gaseous and particulate air pollutant emission trends and uncertainty}

\subsection{Global and regional trends of gaseous and particulate air pollutants emissions}

As further discussed in Sect. 3.2 showing the global anthropogenic emission time series of gaseous pollutants and aerosols of EDGAR v4.3.2, over the period 1970-2012, we estimate increasing global emissions for all pollutants, namely for $\mathrm{SO}_{2}$ emissions from 99 to $103 \mathrm{Mt}$, $\mathrm{CO}$ from 441 to $562 \mathrm{Mt}, \mathrm{NO}_{x}$ from 68 to $122 \mathrm{Mt}$, NMVOC from 119 to $170 \mathrm{Mt}, \mathrm{NH}_{3}$ from 25 to $59 \mathrm{Mt}, \mathrm{PM}_{10}$ from 37 to $65 \mathrm{Mt}$, $\mathrm{PM}_{2.5}$ from 24 to $41 \mathrm{Mt}$, BC from 2.7 to $4.5 \mathrm{Mt}$, and $\mathrm{OC}$ from 9 to $11 \mathrm{Mt}$. However, significant differences are found in the regional emission trends over 1970-2012 and the corresponding sector shares. In the following, we will mainly focus on the emission trends of some representative gases, e.g. $\mathrm{SO}_{2}, \mathrm{CO}, \mathrm{NO}_{x}$, and $\mathrm{PM}_{2.5}$ as representative of the aerosol components. Figures 1-4 show the emission grid maps for the main air pollutants $\left(\mathrm{SO}_{2}, \mathrm{NO}_{x}, \mathrm{CO}\right)$ and aerosols $\left(\mathrm{PM}_{2.5}\right)$ in 1970 and 2012, together with the relative sector contribution for major world regions. Sectors have been aggregated in the following categories: energy (power industry), industry and processes (including industrial combustion and all industrial processes), transport (including both road transport and non-road transport), residential (small-scale combustion and waste treatment), and agriculture. In 1970, $\mathrm{SO}_{2}$ emissions were mainly occurring over the USA (26 Mt) and Eu- rope $(28 \mathrm{Mt})$ from the energy, industry and residential sectors, while in 2012 the major emitters were China (32 Mt) and India (12 Mt) due to the combustion of coal-related fuels, both in power and non-power industries, in addition to the USA (8.2 Mt) and Europe (6.6 Mt). CO emissions in 1970 were dominated by the contribution of the USA (100 Mt), Europe (68 Mt), and China (54 Mt) from the incomplete combustion occurring mainly in the transport and residential sectors, while in 2012 the top emitters were the emerging economies of China (120 Mt), Africa (88 Mt), India (87 Mt), and Latin America ( $73 \mathrm{Mt}$ ), mainly due to the contribution of household combustion and industrial activities, partly resulting from agricultural waste burning (mainly in Latin America and India). Differently from $\mathrm{CO}, \mathrm{NO}_{x}$ emissions result from high-temperature combustion processes, so they are also emitted by power plants and by the transport sector. In 1970, the top emitting regions were the USA (19 Mt) and Europe (14 Mt), while in 2012, they were China (30 Mt), India $(11 \mathrm{Mt})$, Latin America (9.7 Mt), and Africa (5.5 Mt). Emissions from the USA and Europe slightly decreased over the considered time period. Finally, $\mathrm{PM}_{2.5}$ and the other aerosol components are emitted mainly by small-scale combustion and agricultural waste burning activities. In 1970, both industrialized countries like the USA $(2.6 \mathrm{Mt})$ and the EU (3.3 Mt), and emerging economies such as those in China (4.7 Mt), India (3.0 Mt), and Africa (2.4 Mt) represented the top emitting regions, while in 2012, a significant increasing trend is found mainly for India (up to $7.4 \mathrm{Mt}$ ), Africa (up to $5.7 \mathrm{Mt}$ ), and Latin America (up to $3.9 \mathrm{Mt}$ ). A decreasing trend is estimated for all the other regions, in particular for Europe $(1.5 \mathrm{Mt})$, the USA (1.3 Mt), and China (1.2 Mt), reaching less than half of the corresponding $1970 \mathrm{PM}_{2.5}$ emissions. Organic carbon emissions increased from 1970 to 2012 only by a factor 1.2 compared to the other aerosol components $\left(\mathrm{PM}_{10}, \mathrm{PM}_{2.5}\right.$, and $\mathrm{BC}$ ), which increased by a factor 1.7. The trend in OC emissions is mainly driven by the residential combustion of biomass and agricultural waste burning sectors for which we find OC emissions changing less rapidly than for the other sectors. We further note that EDGAR OC emission factors in certain sectors, such as chemical processes, iron and steel production, non-metallic mineral production, etc., are generally low, but are highly uncertain due to a lack of observed emission factors.

\subsection{Comparison of the EDGAR v4.3.2 time series with other global inventories}

Figure $5 \mathrm{a}$ and $\mathrm{b}$ show the comparison of global anthropogenic emission time series of gaseous pollutants and aerosols as estimated by the different versions of the EDGAR database, namely EDGAR v4.2 (EC-JRC/PBL, 2011; http://edgar.jrc.ec.europa.eu/overview.php?v=_42, last access: October 2018, https://doi.org/10.2904/EDGARv4.2), EDGAR v4.3.1 (Crippa et al., 2016a; http://edgar.jrc.ec. europa.eu/overview.php?v=_431, last access: October 2018, 

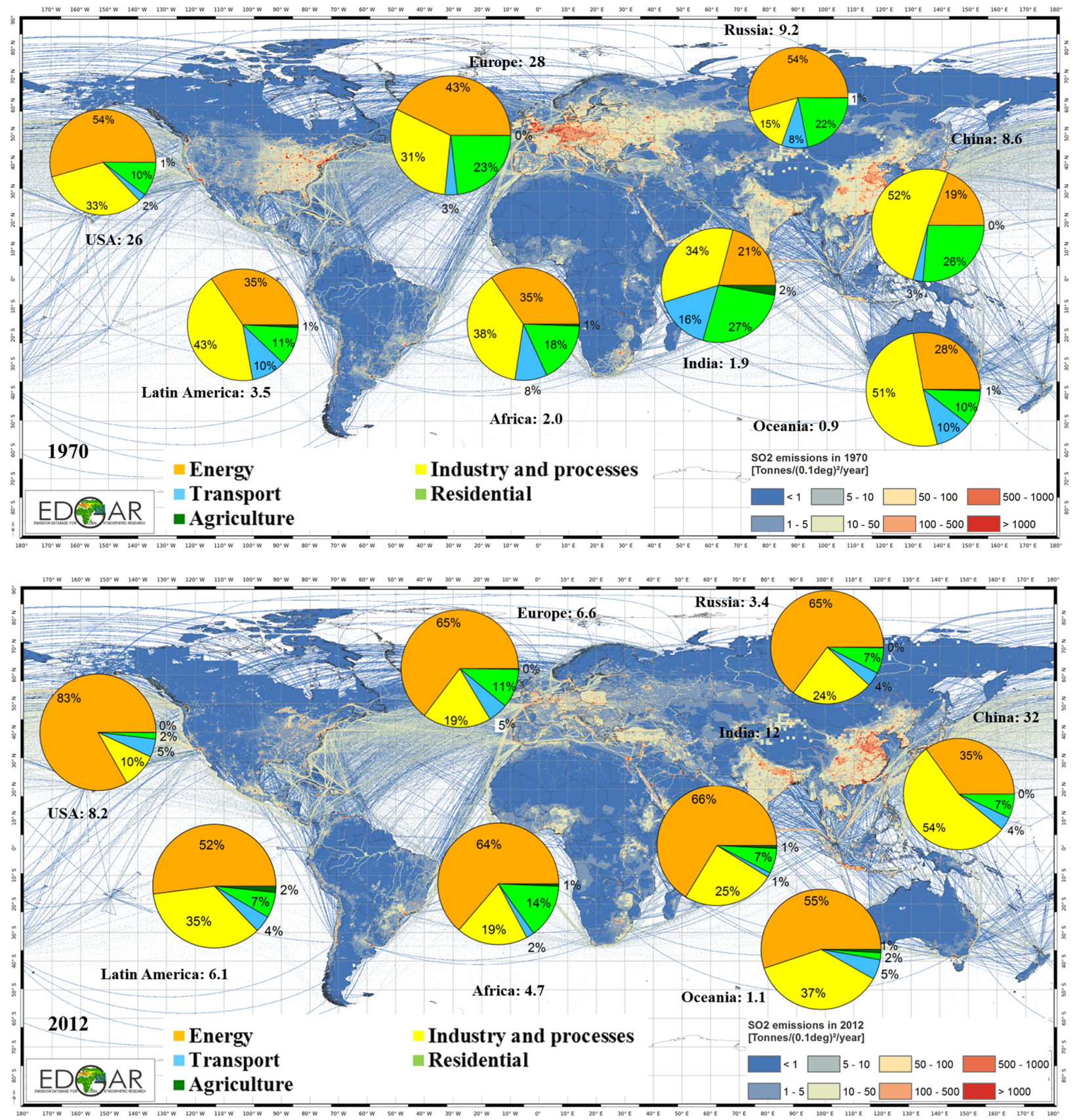

Figure 1. $\mathrm{SO}_{2}$ emission grid maps and relative contribution of aggregated EDGAR sectors (energy, industry and processes, transport,

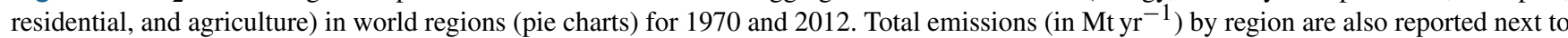
each pie chart.

https://doi.org/10.2904/JRC_DATASET_EDGAR), EDGAR v4.3.2, and several other global inventories such as HTAP v2.2 (Janssens-Maenhout et al., 2015), MACCity (Granier et al., 2011), CEDS (Hoesly et al., 2017), ECLIPSEV5a (Klimont et al., 2017), and that of Lamarque et al. (2010) and Klimont et al. (2013). Note that not all global inventories cover all pollutants and time series. The comparison of different emission inventories allows us to explore the range of global emission estimates and to identify the pollutants for which the emissions show larger discrepancies. For the aerosols, a region- and sector-specific comparison between EDGAR v4.3.2 and ECLIPSEv5a is provided in the Supplement (Sect. 1.1), showing a high agreement for $\mathrm{PM}_{10}$ (also within a few percent at the regional level) and less good agreement for the other aerosol components. Comparing global totals, we find a $1 \%$ deviation for $\mathrm{PM}_{10}, 12 \%$ 

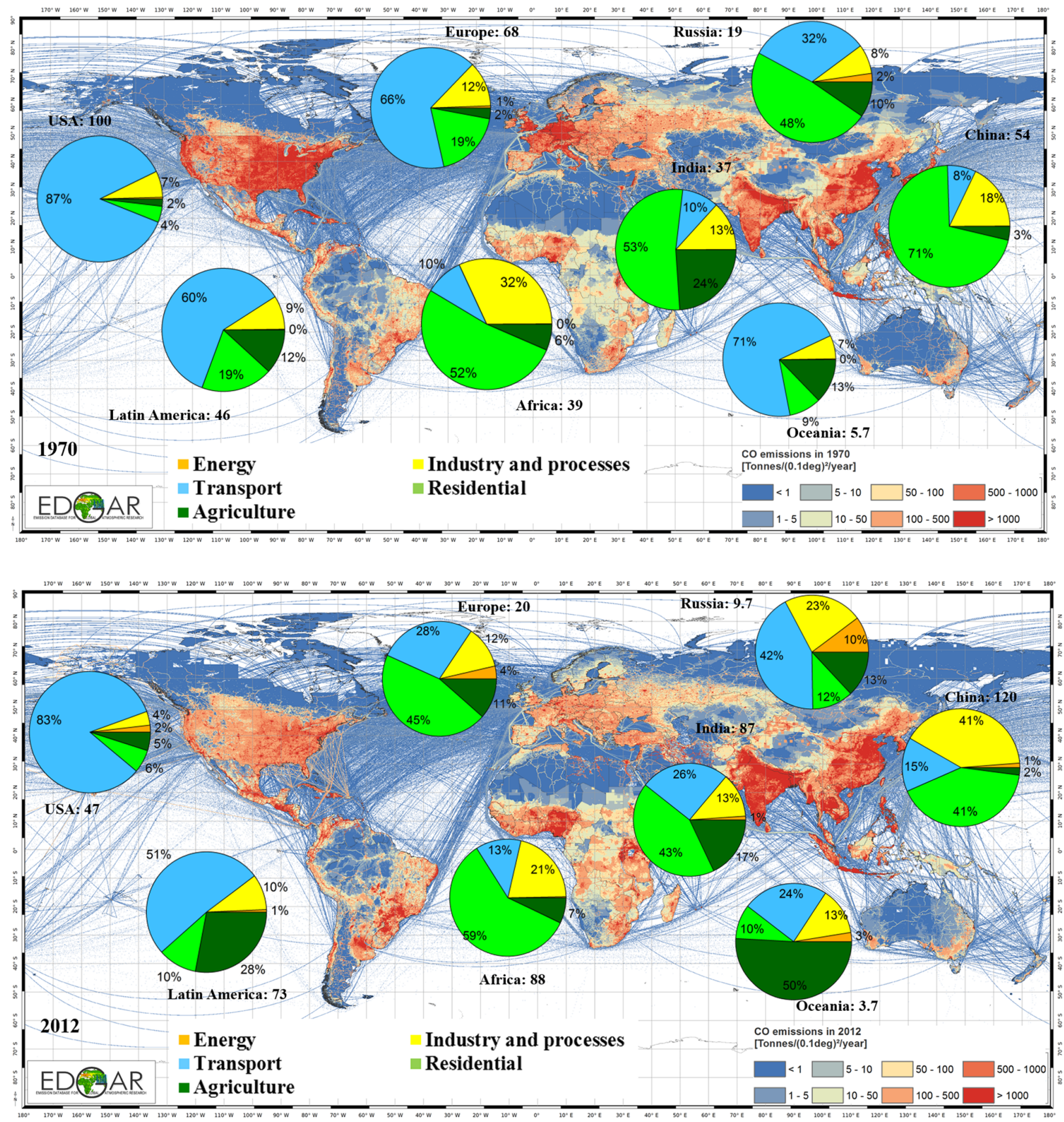

Figure 2. CO emission grid maps and relative contribution of aggregated EDGAR sectors (energy, industry and processes, transport, residential, and agriculture) in world regions (pie charts) for 1970 and 2012. Total emissions (in $\mathrm{Mt} \mathrm{yr}^{-1}$ ) by region are also reported next to each pie chart.

for $\mathrm{PM}_{2.5}, 17 \%$ for $\mathrm{OC}$, and $43 \%$ for $\mathrm{BC}$ (mainly due to the likely underestimation of the EDGAR v4.3.2 primary aerosol emissions compared to the ECLIPSEV5a of coal combustion in residential activities in China and India). Rather good agreement for the top emitting regions is found, while larger discrepancies are calculated for low emitting countries. Part of the discrepancies between ECLIPSEV5a and EDGAR v4.3.2 can be explained when not accounting for the non- commercially sold fuels such as diesel to run communication towers in India (Klimont et al., 2017), or coal and rubbish (Klimont et al., 2017; Bond et al., 2007), and wood, wood waste, and pellets (Denier van der Gon et al., 2015) used for residential purposes. In addition, the combustion efficiency, different technologies, and abatement measures applied to reduce pollutant emissions in the residential sector are very uncertain as well. Because of the global coverage and the lack 

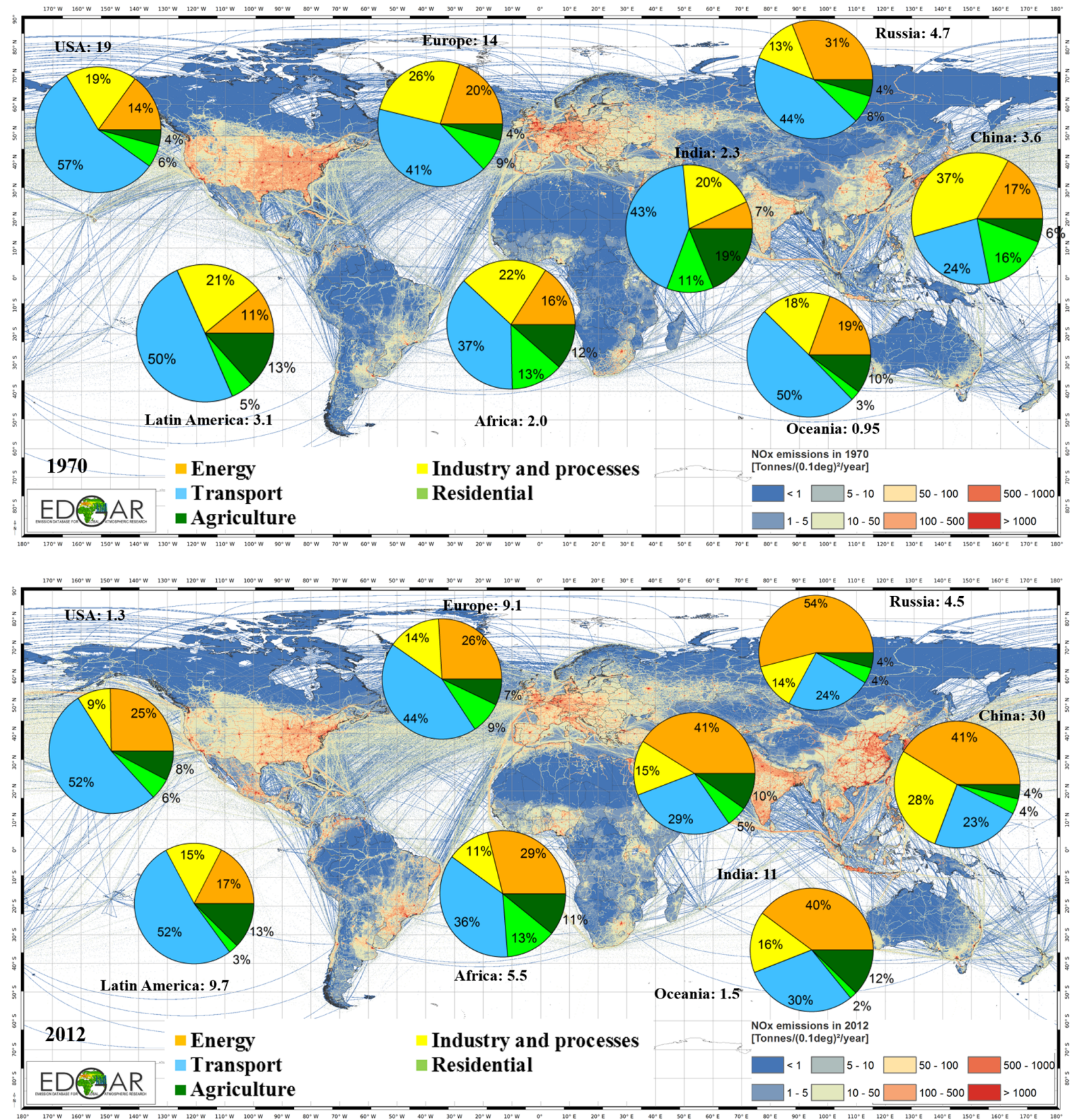

Figure 3. $\mathrm{NO}_{x}$ emission grid maps and relative contribution of aggregated EDGAR sectors (energy, industry and processes, transport, residential, and agriculture) in world regions (pie charts) for 1970 and 2012 . Total emissions (in $\mathrm{Mt} \mathrm{yr}^{-1}$ ) by region are also reported next to each pie chart.

of local information on super emitters (in particular superemitting vehicles and cold starts), the particulate emissions of EDGAR v4.3.2 are known to miss the $10 \%$ most highly polluting activities with a 10 times larger $\mathrm{PM}_{2.5}$ emission factor for some countries (Klimont et al., 2017, and references therein).

The differences between the different EDGAR versions can be explained by data updates (e.g. activity data as dis- cussed online for the difference between v4.2 and v4.1, EFs for $\mathrm{SO}_{2}, \mathrm{PM}$ and NMVOC, the latter documented by Huang et al., 2017, in the section on technologies and abatements). The two most recent EDGAR releases, v4.3.1 and v4.3.2, are consistent for almost all sources, except for the biofuel consumption in the residential sector for which the IEA activity data were known to have changed method (towards higher Tier) relying on comparable activity data. A signif- 

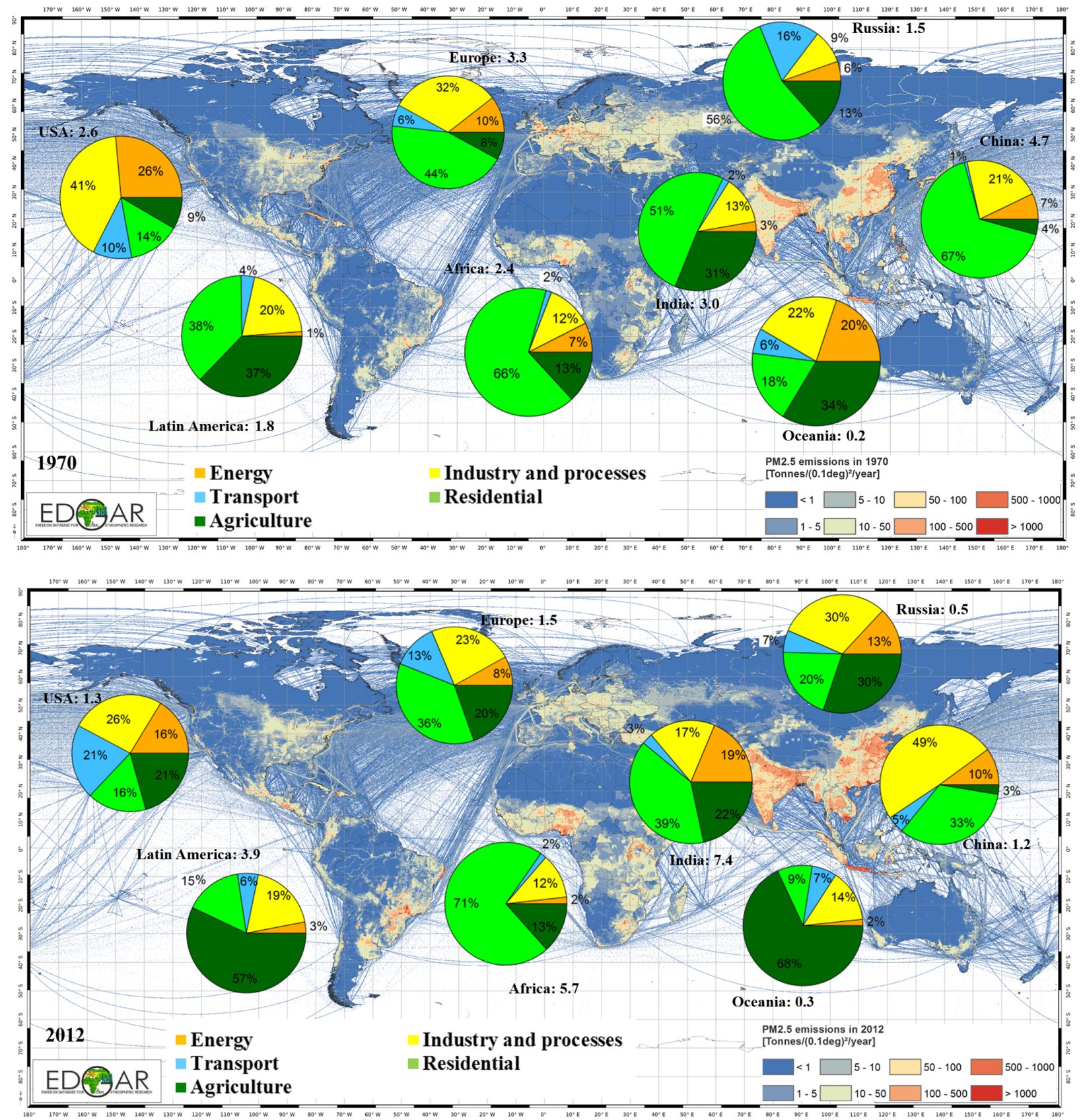

Figure 4. $\mathrm{PM}_{2.5}$ emission grid maps and relative contribution of aggregated EDGAR sectors (energy, industry and processes, transport, residential, and agriculture) in world regions (pie charts) for 1970 and 2012. Total emissions (in $\mathrm{Mt} \mathrm{yr}^{-1}$ ) by region are also reported next to each pie chart.

icant update has also been made for the ferroalloy production sector, production of chemicals, production of fuels, residential sector, and solid waste, mainly affecting $\mathrm{CO}$ emissions. NMVOC emissions are higher in EDGAR v4.3.2 compared to earlier versions of the EDGAR estimates, mainly due to updates of the emission factors for the NMVOC losses in the gas distribution sector. NMVOC EFs for this sector have been revised by checking the ratio of total NMVOC to methane. Based on the information about fugitive emissions in the gas distribution sector provided by Salway et al. (2002), in EDGAR v4.3.2, we assume a ratio of $10.5 \%$ for 1990 and of $18.9 \%$ for 2000 between NMVOC and $\mathrm{CH}_{4}$ EF. Note that $\mathrm{CH}_{4}$ emission factors have been also revised in EDGAR v4.3.2 by being compared to former versions as documented by Janssens-Maenhout et al. (2017), as suggested by Höglund-Isaksson et al. (2017). 
The Lamarque et al. (2010) inventory shows a huge underestimation of $\mathrm{NO}_{x}$ emissions that we cannot fully explain. Finally, for EDGAR v4.3.2, a quality control procedure with a full evaluation of the time series and grid maps checking for gaps in the 1970-2012 time series or outliers and the closure of the particulate matter mass balance (e.g. $\mathrm{PM}_{2.5} \leq \mathrm{PM}_{10}$ and $\mathrm{BC}+\mathrm{OC} \leq \mathrm{PM}_{2.5}$ ) has been performed. The closure of PM mass balance needs to be verified, since each PM component is independently estimated from the others.

\subsection{Regional air pollutant uncertainty analysis}

Crippa et al. (2017) provide uncertainty estimates for gaseous and particulate matter emissions for all world regions based on the uncertainty estimates of the activity data and the emission factors for each emission sector, pollutant, and country (see Eq. 2);

$$
\begin{array}{r}
\sigma(C, x, t)=\left(\sum _ { i } \left(\sigma_{\mathrm{AD}_{i}(C, t)}^{2}+\sigma_{\mathrm{TECH}_{i}(C, t)}^{2}+\sigma_{\mathrm{EOP}_{i}(C, t)}^{2}\right.\right. \\
\left.\left.+\sigma_{\mathrm{EF}_{i}(C, x, t)}^{2}+\sigma_{\mathrm{RED}_{i}(C, x, t)}^{2}\right)\left(\frac{\mathrm{EM}_{i}(C, x, t)}{\mathrm{EM}_{\mathrm{tot}}(C, x, t)}\right)^{2}\right)^{1 / 2}
\end{array}
$$

with the standard deviations $\sigma$ of the activity, technology, end-of-pipe data, emission factors, and reduction factors for each pollutant $x$ and country $C$.

Based on the assumption of lognormal distribution of the calculated uncertainties (Bond et al., 2004), we evaluated the upper and lower range of emission estimates by multiplying and dividing the EDGAR v4.3.2 base emissions by $\left(1+\sigma_{x, c}\right)$, respectively. Among all air pollutants (refer to Table $\mathrm{S} 4$ ), $\mathrm{SO}_{2}$ has the smallest uncertainty at the regional level (variation between $14.4 \%$ and $47.6 \%$ in 2012); the uncertainty of $\mathrm{NO}_{x}$ varies in 2012 between $17.2 \%$ and $69.4 \%$ (with the exception of Brazil, which reaches an uncertainty up to $123.5 \%$ ), $\mathrm{CO}$ varies between $25.9 \%$ and $64.6 \%$ for industrialized countries (and up to $123.4 \%$ for emerging and developing economies), and NMVOC varies between $32.7 \%$ and $73.6 \%$ for industrialized countries and above $100 \%$ (up to $147.5 \%$ ) for non-Annex I countries and emerging economies. The uncertainty of $\mathrm{NH}_{3}$ is the largest among all pollutants because of the high uncertainty of both agricultural statistics and emission factors (range of variation in 2012: $186 \%$ and $294.4 \%$ ). The primary aerosol emissions are generally characterized by rather high uncertainties, with a range of variation in 2012 between $57.4 \%$ and $109.1 \%$ for $\mathrm{PM}_{10}$, between $49 \%$ and $91.4 \%$ for $\mathrm{PM}_{2.5}$, between $46.8 \%$ and $92 \%$ for $\mathrm{BC}$, and between $88.7 \%$ and $153.2 \%$ for $\mathrm{OC}$, consistent with the results of Bond et al. (2004) that report a factor of 2 for the uncertainty of the organic components. As discussed earlier, higher uncertainties in PM emissions might come from super-emitting vehicles that are not considered in this study. Therefore, the error band range presented by Klimont et al. (2017) for these components is much wider than what we find in our work, due to the high uncertainty. In general, the emission uncertainty is reducing over time for industrialized countries (e.g. $\mathrm{SO}_{2}, \mathrm{CO}, \mathrm{PM}_{2.5}$ for the USA and EU-28 and to a minor extent also $\mathrm{NO}_{x}$ ), while the uncertainty band is larger for China and developing countries in particular due to the larger contribution of highly uncertain sector. We note that our uncertainty analysis using the relative values only estimates the uncertainty on the estimated part of the emissions and does not account for the missing super-emitting part. In the case of PM our uncertainty band might be underestimated by a factor of 2 .

The uncertainty estimates shown in Fig. 6 as well as in Tables S4 and Fig. S1.4 are strongly determined by the relative contribution of each anthropogenic sector over time to the total emissions of a certain region, therefore we do not always observe a decreasing trend in the corresponding overall component uncertainty. For example, the uncertainty of $\mathrm{NH}_{3}$ emissions in China (Fig. S1.4) is growing at a faster rate compared to the corresponding emissions due to the very large uncertainty of the agricultural sector (use of feritlizers) and manure management, whose contribution represented $69 \%$ of total Chinese emissions in 1970 and $97 \%$ in 2012. Similarly, the uncertainty band of OC emissions in China (Fig. S1.4) shows a larger increase from 1985 to 1992 compared to the corresponding emissions due to the larger share of the residential combustion of biomass and coal emissions during those years, which is very uncertain.

\section{Emission metrics: implied emission factors, per capita and per GDP emissions}

\subsection{Trends in implied emission factors}

Implied emission factors can be used as a metric of emission intensity of anthropogenic activities for each country, and they have been calculated following the methodology by Janssens-Maenhout et al. (2015). Figure 7 shows the implied emission factors calculated for aggregated emission sectors (as defined in Sect. 2.1), namely energy, industry, residential, transport, and agriculture from the EDGAR v4.3.2 database. Box plot statistics (10th, 25th, 50th, 75th, and 90th percentiles) represent the variability amongst countries of the implied EFs in 2010 (2010 has been chosen for comparability with the HTAP v2.2 inventory). The variability across countries is also investigated with the representation of the median implied EFs for low-income (LIC) and high-income (HIC) countries, showing much higher implied EFs for LICs than for HICs for all pollutants and sectors. The comparison with the corresponding implied EFs obtained for the HTAP v2.2 emission data is also reported (refer to Janssens-Maenhout et al., 2015), showing rather good agreement with the exception of the industrial sector for most of the pollutants and the agricultural sector for $\mathrm{NH}_{3}$, which is due to the different emissions and activity data used for these two emission inventories. Table S1 of the Supplement (Sect. 1.2) shows a 
(a)

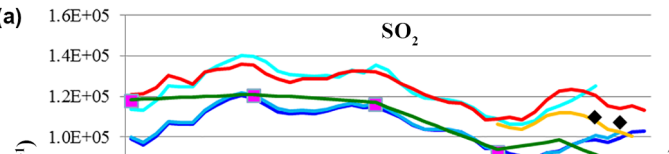

$8.0 \mathrm{E}+04$

$\overbrace{}^{N}$

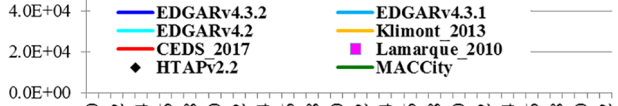

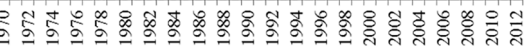
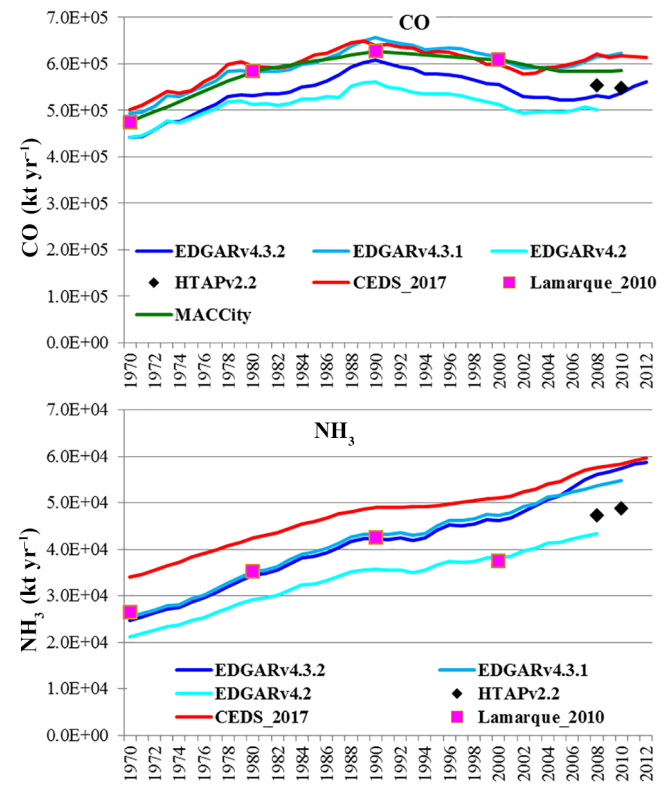

(b)
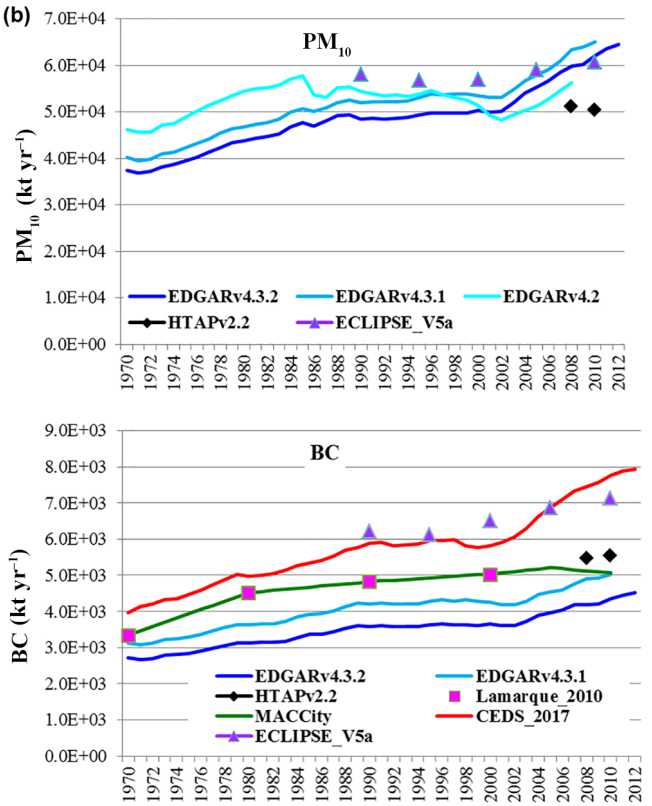
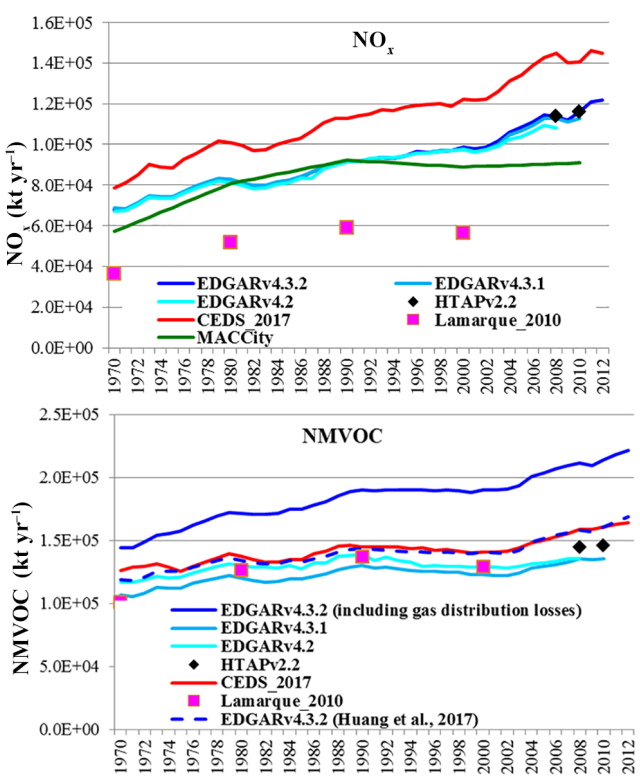
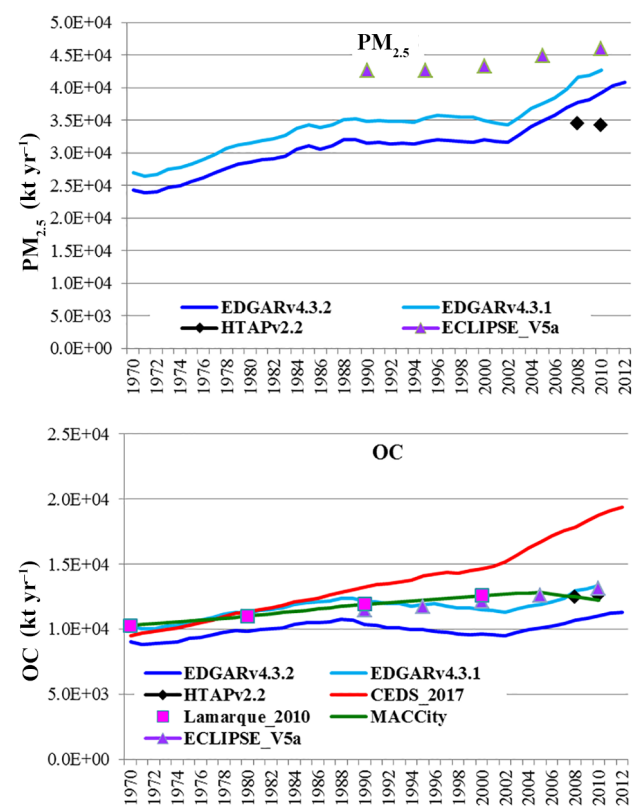

Figure 5. (a) Comparison of the global emission time series (1970-2012) of gaseous pollutants provided by different global emission inventories. The NMVOC graph presents two estimates for the EDGAR v4.3.2 database, one referring to the work of Huang et al. (2017) and the second one related to this study, which also includes the emissions from the gas distribution losses. (b) Comparison of global emission

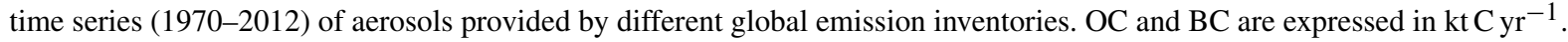



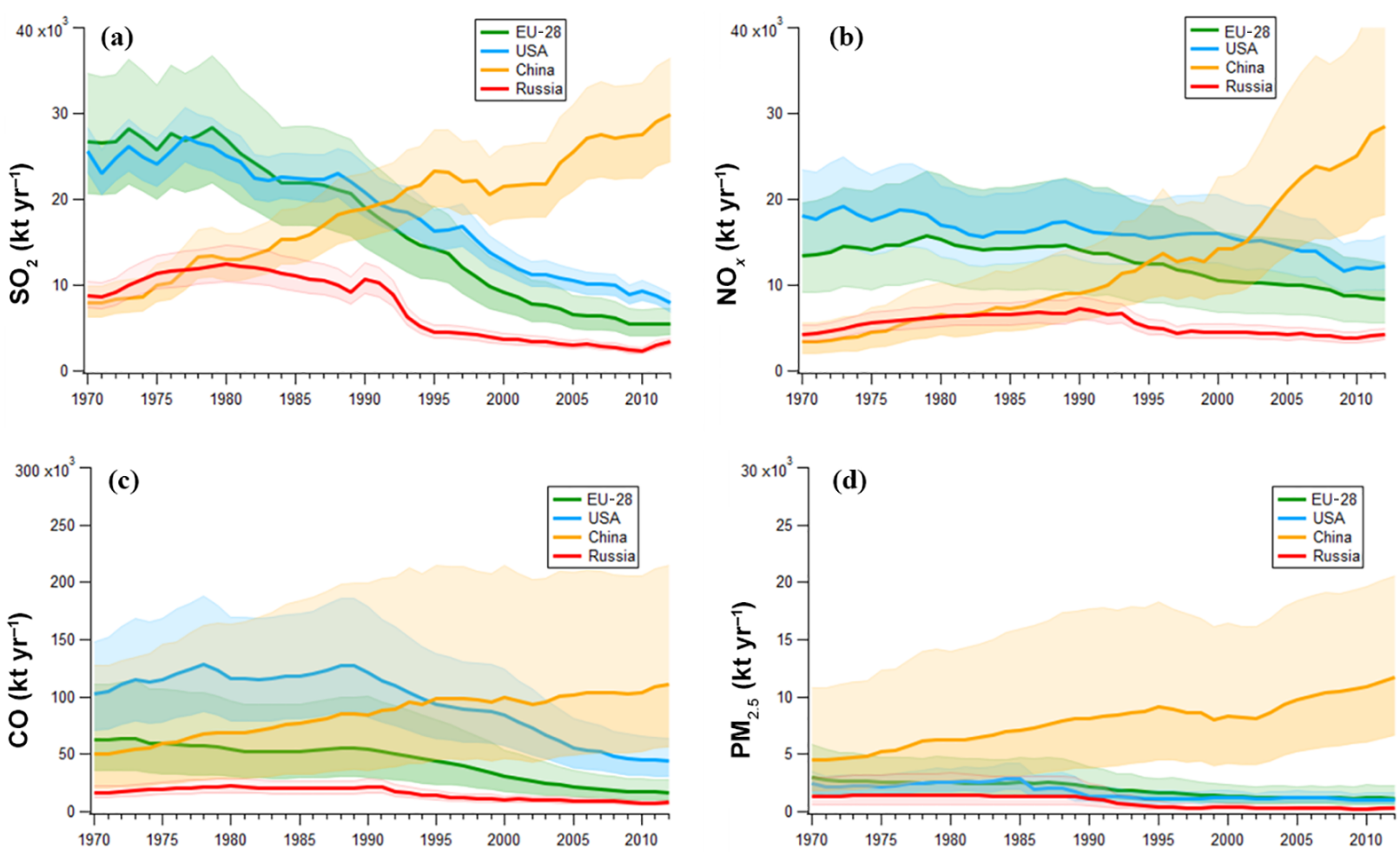

Figure 6. Emission time series of $\mathrm{SO}_{2}, \mathrm{NO}_{x}, \mathrm{CO}$, and $\mathrm{PM}_{2.5}$ with uncertainty bands for top emitting countries or regions (China, the USA, Russia, and EU-28).

detailed comparison of the implied emission factors of selected regions (EU-28, the USA, China, India, Russia, and Japan) with the global median values for all pollutants and sectors.

The highest implied EFs for most of the pollutants emitted in the energy sector are found in developing regions, such as Africa, Latin America, Indonesia, and India, but also in Central Asia and the Middle East, while lower values are observed for industrialized countries (the USA, Europe, and Japan), Korea, and China. A different picture emerges for the industrial and transport sectors, where, in addition to the aforementioned regions, very high implied EFs are also computed in China. On the contrary, the implied EFs for $\mathrm{NH}_{3}$ related to the emissions of the transport sector are larger for the USA, Oceania, Canada, Korea, and Japan due to the deployment of gasoline vehicles equipped with $\mathrm{NO}_{x}$ reduction catalysts (producing $\mathrm{N}_{2}$ and some other nitrogen components such as $\mathrm{NH}_{3}$ ) and the oxidization of $\mathrm{CO}$ and unburned hydrocarbons (HC) to $\mathrm{CO}_{2}$ and $\mathrm{H}_{2} \mathrm{O}$. The residential sector shows the smallest range of variation of the implied EFs for most of the gaseous pollutants, which is due to the fact that fewer controls are applied to both the fuel used and combustion temperature (although industrialized countries have, in general, lower $\mathrm{CO}$ emission factors due to the deployment of burners with higher combustion efficiencies). Despite of the low range in EFs, we should bear in mind that PM emission factors for the residential sector are the highest compared to all other activities, with the exception of some industrialized countries where the implementation of particulate filters on the stoves could have reduced PM emissions significantly.

For 1970-2012, the implied EFs were mostly decreasing. The implied $\mathrm{EF}$ for $\mathrm{SO}_{2}$ for energy activities decreased on average by ca. $60 \%$, with a range of variation between $4 \%$ and $93 \%$ depending on the region. They ranged between 0.94 and $0.1 \mathrm{t} \mathrm{TJ}^{-1}$ for OECD Europe, between 0.97 and 0.6 $\mathrm{t} \mathrm{TJ}^{-1}$ for central Europe, between 1.1 and $0.25 \mathrm{t} \mathrm{TJ}^{-1}$ for the USA, and between 1.03 and $0.23 \mathrm{tTJ}^{-1}$ for China. In the global average, $\mathrm{NO}_{x}$ implied that EFs were decreasing from 1970 to 2012 with a smaller rate compared to $\mathrm{SO}_{2}$, which was ca. $30 \%$. The residential sector is characterized by rather stable implied EFs (both for $\mathrm{CO}$ and the aerosol components), showing an average decrease of $30 \%$ for $\mathrm{CO}$ and $35 \%$ for $\mathrm{PM}_{2.5}$. Africa and other developing regions show negligible variation in implied EFs over time due to the enhanced contribution of residential activities and higher emissions from biomass combustion. The implied EFs for the road transport sector were strongly decreasing for $\mathrm{NO}_{x}$ and $\mathrm{CO}$, particularly for industrialized countries from 1970 to 2012, with a global average decrease of $37 \%$ for $\mathrm{NO}_{x}$ and $67 \%$ for CO. The implied EFs for CO for the road transport sector varied over time, from 7.7 to $1.7 \mathrm{t} \mathrm{TJ}^{-1}$ for the USA, from 8.8 to $0.4 \mathrm{t} \mathrm{TJ}^{-1}$ for OECD Europe, from 7.2 to 

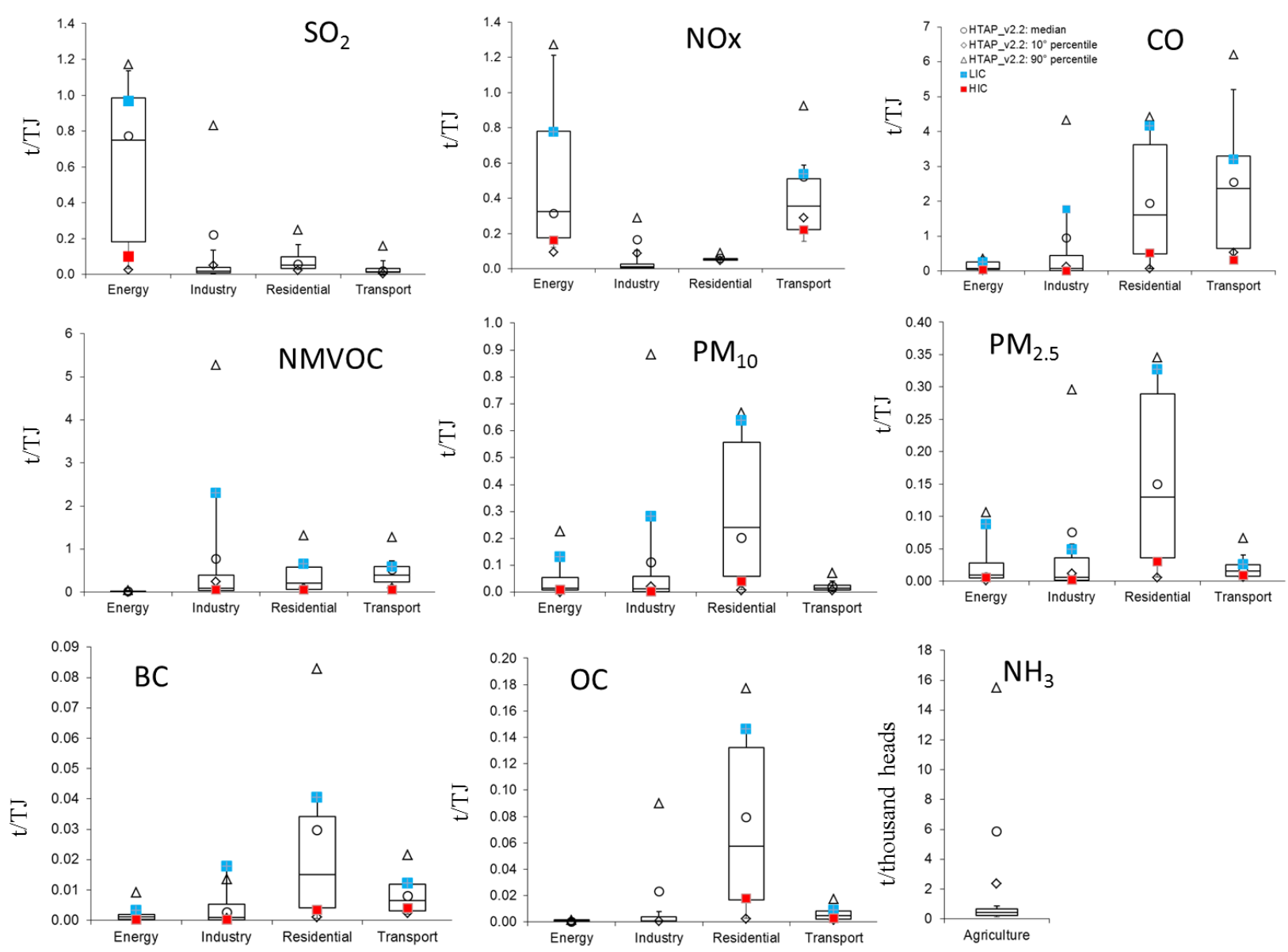

Figure 7. Implied emission factors calculated for 226 countries for the aggregated emission sectors (energy, industry, residential, transport, and agriculture) from the EDGAR v4.3.2 database. Box-plot statistics (10th, 25th, 50th, 75th, and 90th percentile) represent the country variability of the implied EFs in 2010. The comparison with the corresponding implied EFs obtained for the HTAP v2.2 (Janssens-Maenhout et al., 2015) emission data, which excludes agricultural waste burning and field burning, is also reported. In addition, we report the median of low-income and high-income countries (with light blue and red makers, respectively) for the sectors showing the larger variability across countries. Table S1 of the Supplement reports implied EFs for all pollutants and sectors for selected regions differing in income level and the comparison with the global average.

$0.9 \mathrm{t} \mathrm{TJ}^{-1}$ for central Europe, and from 16 to $1.9 \mathrm{t} \mathrm{TJ}^{-1}$ for China.

\subsection{Trends in per capita and per GDP emissions for different groups of countries}

In order to compare countries with different degrees of development and different population sizes, 2010 per capita emissions (Fig. 8) have been calculated for each pollutant and income level. The definition of country groups based on their income is consistent with the approach adopted by Janssens-Maenhout et al. (2015) and reported in Table S5. The comparison with the HTAP v2.2 per capita emission estimates (Janssens-Maenhout et al., 2015) is also shown in Fig. 8 as the HTAP v2.2 inventory based on official national inventory data. In addition, the emissions per income (or per GDP, corrected for the purchasing power parity in
2010; IMF/WEO, 2017) are compared for the different pollutants in Fig. 9. Tables S2 and S3 of Sect. S1.3 of the Supplement compare these values by macro region. HICs show the highest per capita emissions for most of the gaseous pollutants, representing the intensity of the anthropogenic activities associated with their industrial development. On the contrary particulate matter per capita emissions are higher for low and low-middle income countries compared to highincome countries due to the lack of air pollution control equipment, such as particulate filters and electrostatic precipitators, together with the larger deployment of biomass based fuel, leading to high uncontrolled PM emissions, mainly for household purposes. Among all air pollutants, $\mathrm{CO}$ shows the highest emissions for GDP and the largest variation over all countries, reflecting the degree of economic activity in the world. Similarly to the per capita emissions, industrialized 
countries have lower emissions of PM when their GDPs are higher, while China, India, and emerging or developing countries (Table S3) show the highest PM emissions for GDP due to the deployment of less clean technologies.

\section{Ratios of co-emitted species}

Combustion processes emit not only $\mathrm{CO}_{2}$ but also a variety of other air pollutants, like $\mathrm{NO}_{x}, \mathrm{CO}, \mathrm{SO}_{2}$, and $\mathrm{PM}$. Depending on the fuel type, combustion technology, process, abatement measures, etc., source-related emission ratios of co-emitted species are measured. In particular, very local combustion sources could alter the concentrations of $\mathrm{CO}_{2}$ and other pollutants, and an analysis of the changes of the relative abundances of such pollutants could indicate and quantify the type of sources present in a certain area, when using the appropriate spatial resolution. Large-scale events such as fires can be distinguished using $\mathrm{NO}_{2}$ and $\mathrm{CO}$ in addition to $\mathrm{CO}_{2}$, as shown by Silva and Arellano (2017). These fire emissions are not included in our database. For smaller-scale sources and point sources, high spatial resolution and plume modelling are needed to isolate the single sources, as shown by Nassar et al. (2017) in the case of a power plant. EDGAR does not have this high resolution, but the emission factors for the single multi-pollutant sources are available with the implied emission factors, and the locations of the point sources, e.g. for the energy sector, are available in the sector-specific grid map.

The EDGAR inventory provides estimates of co-emitted pollutants in addition to the greenhouse gases; however, as discussed in Sect. 3, even emissions from combustion processes are often poorly characterized, particularly in developing regions due to scarce information on fuel consumed, deployed technologies, and applied abatement measures. In order to better constrain emission inventory estimates, groundbased and satellite measurements can partly complement the information related to combustion emissions. For example, Silva and Arellano (2017) focus their study on satellite observations of $\mathrm{CO}_{2}, \mathrm{NO}_{2}$ and $\mathrm{CO}$ emitted by combustion sources and show that the analysis of co-emitted species could provide constraints on emission inventories, and be useful in monitoring trends and understanding regional-scale combustion processes. Due to the global coverage, historical time series, and consistent emission estimates for both greenhouse gases and air pollutants and world countries, the EDGAR emissions of $\mathrm{CO}_{2}$ and co-emitted pollutants could be coupled with the information retrieved by satellite measurements. The work by Streets et al. (2013) provide an overview on the current capabilities and limitations of satellite observations to measure air pollutant emissions such as $\mathrm{SO}_{2}, \mathrm{NO}_{x}, \mathrm{CO}$, NMVOC, $\mathrm{NH}_{3}, \mathrm{PM}, \mathrm{CH}_{4}$, and $\mathrm{CO}_{2}$ as well as the methodology behind their emission estimation. Several other studies analyze satellite retrievals of emission ratios of co-emitted pollutants to identify multi-pollutant sources and possible proxies to estimate the emissions of other compounds from $\mathrm{CO}_{2}$ emissions, for example (Konovalov et al., 2016; Fioletov et al., 2017; Geng et al., 2017).

In this section, we analyze the emission ratios of coemitted pollutants as provided by the EDGAR database (this calculation is not performed at the grid-cell level but considers the aggregated technology-based emission factors and activities). These emission ratios are determined by the type of fuel and the technology and differ by region as such (Fig. 10). Emission ratios of co-emitted species are strongly dependent on human activities and technologies in the emitting sector, which also change over time. In general we find lower emission ratios of each species to $\mathrm{CO}_{2}$ as well as a smaller range of variation in 2012 than in 1970 for most of the sectors (see also Fig. 11); this is because of a decoupling of air pollutant emissions from energy production due to global development towards clean air technologies. The global emission ratios of $\mathrm{NO}_{x} / \mathrm{CO}_{2}$ (and $\mathrm{NO}_{x} / \mathrm{CO}$ ) are the highest for the power generation sector due to the high combustion temperatures producing high levels of $\mathrm{NO}_{x}$ and low $\mathrm{CO}$, as shown in Fig. 11. The $\mathrm{NO}_{x} / \mathrm{CO}_{2}$ overall emission ratio in Mexico shows an increasing trend because of the corresponding increasing ratios of the transport and residential sectors (see Figs. 13 and 14). The $\mathrm{CO} / \mathrm{CO}_{2}$ emission ratio is the highest for the road transport and partly the residential sectors (both in 1970 and 2012) due to the low efficient combustion of vehicles and small scale combustion activities compared to power plants. The spike observed for Indonesia in 1990 is partly artificial and related to the contribution of industrial combustion activities, which were not estimated for earlier years. The $\mathrm{SO}_{2} / \mathrm{CO}_{2}$ emission ratio shows the largest decrease from 1970 to 2012, particularly affecting the power generation sector due to the implementation of international conventions (e.g. CLRTAP) that regulate acidifying gases and air quality together with the implementation of regulations on the sulfur content of the fuels. The $\mathrm{PM}_{10} / \mathrm{CO}_{2}$ emission ratio is the largest for the residential sector due to the scarce implementation of abatement measures, lack of strict regulations, low quality fuels used for household purposes, and often inefficient combustion processes.

The analysis of the power generation (energy) sector (Fig. S3a) for different countries reveals mainly decreasing trends for the $\mathrm{NO}_{x} / \mathrm{CO}$ ratios, but there is no generic trend for the ratio of $\mathrm{CO}, \mathrm{NO}_{x}$, and $\mathrm{SO}_{2}$ over $\mathrm{CO}_{2}$. The largest reductions over time are computed for the $\mathrm{SO}_{2} / \mathrm{CO}_{2}$ ratios for developed countries, in particular, those with a fuel shift from coal to gas such as OECD Europe as well as the USA and Russia. Decreases in $\mathrm{NO}_{x} / \mathrm{CO}_{2}$ ratios are present in many countries such as OECD Europe, the USA, Japan, and Korea as well as Mexico, northern Africa, southeastern Asia, and China, reflecting the penetration of low- $\mathrm{NO}_{x}$ burners. $\mathrm{NO}_{x} / \mathrm{CO}_{2}$ and $\mathrm{CO} / \mathrm{CO}_{2}$ ratios are high and increase until the year 2000, when they reach a plateau for the least developed regions such as eastern Africa and Central America. Our analysis of the transport sector (Fig. S3b) shows large 

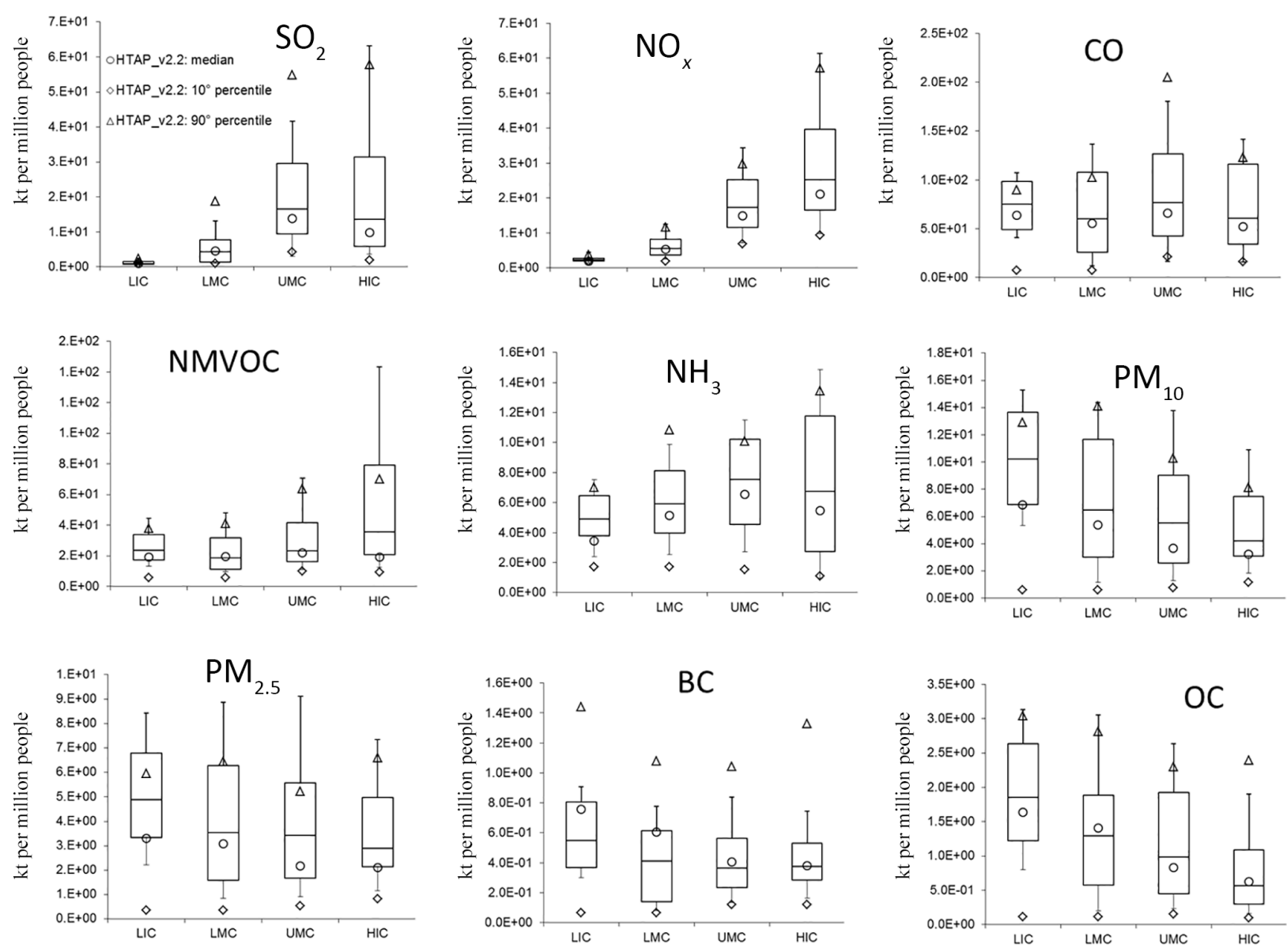

Figure 8. Per capita air pollutant emissions in 2010 (for comparability with the HTAP v2.2 inventory) per substance and group of countries are represented as box plots (10th, 25th, 50th, 75th, and 90th percentile): low income (LIC), low-middle income (LMC), upper-middle income (UMC), and high income (HIC). The comparison with the HTAP v2.2 estimates (circle is the median, diamond is the 10th percentile, and triangle is the 90th percentile; refer to Janssens-Maenhout et al., 2015) is also reported.

differences between 1970 and 2012 due to a large penetration of clean air technologies, where the $\mathrm{CO}$ and $\mathrm{NO}_{x}$ emission factors have been decreasing considerably along with the penetration of the vehicle emission standards, contrary to the $\mathrm{CO}_{2}$ emission factor. The degree of regional development towards environmentally enhanced vehicles is directly reflected in the graphs of Fig. 13 showing a strong decrease for the $\mathrm{CO} / \mathrm{CO}_{2}$ ratio in developed regions, while China has shown an accelerated decrease since the 2000s. Even though the residential sector is not expected to show the same penetration of clean air technologies as the transport sector, large decreases of the $\mathrm{CO} / \mathrm{CO}_{2}$ ratios over time are generally calculated for almost all world regions. In particular $\mathrm{SO}_{2} / \mathrm{CO}_{2}$ ratios have decreased due to changes in the type of fuel used, most strongly in the USA, Europe, Russia, and Japan but also in China. However, contrary to $\mathrm{CO} / \mathrm{CO}_{2}$, the $\mathrm{NO}_{x} / \mathrm{CO}_{2}$ ratios did not show large improvements, which yielded also to the increases in $\mathrm{NO}_{x} / \mathrm{CO}$, as presented in Fig. S3c.

\section{Gridded emissions}

Gridded emissions represent an asset of the EDGAR database widely used by the scientific air quality and climate modelling communities. As mentioned in the introduction, in this section we do not analyze all the detailed information included within each grid map (EDGAR comprises 42 years of grid maps for 26 aggregated sectors and 9 substances), but we rather try to inform the users about the type of information included in the gridded emissions and suggest possible use of such data and analysis. In order to particularly address the satellite community, we will focus on the emissions of the latest 5 years available in EDGAR v4.3.2 (2007-2012) in the following sections, namely investigating (i) the possibility to use emission sector shares at the grid-cell level (Sect. 6.1) to retrieve from total column measurements the sector composition of the emissions and (ii) the evolution of high emitting areas over time and space (hot-spot evolution, Sect. 6.2). We selected a time period of 5 years because of detectable emis- 

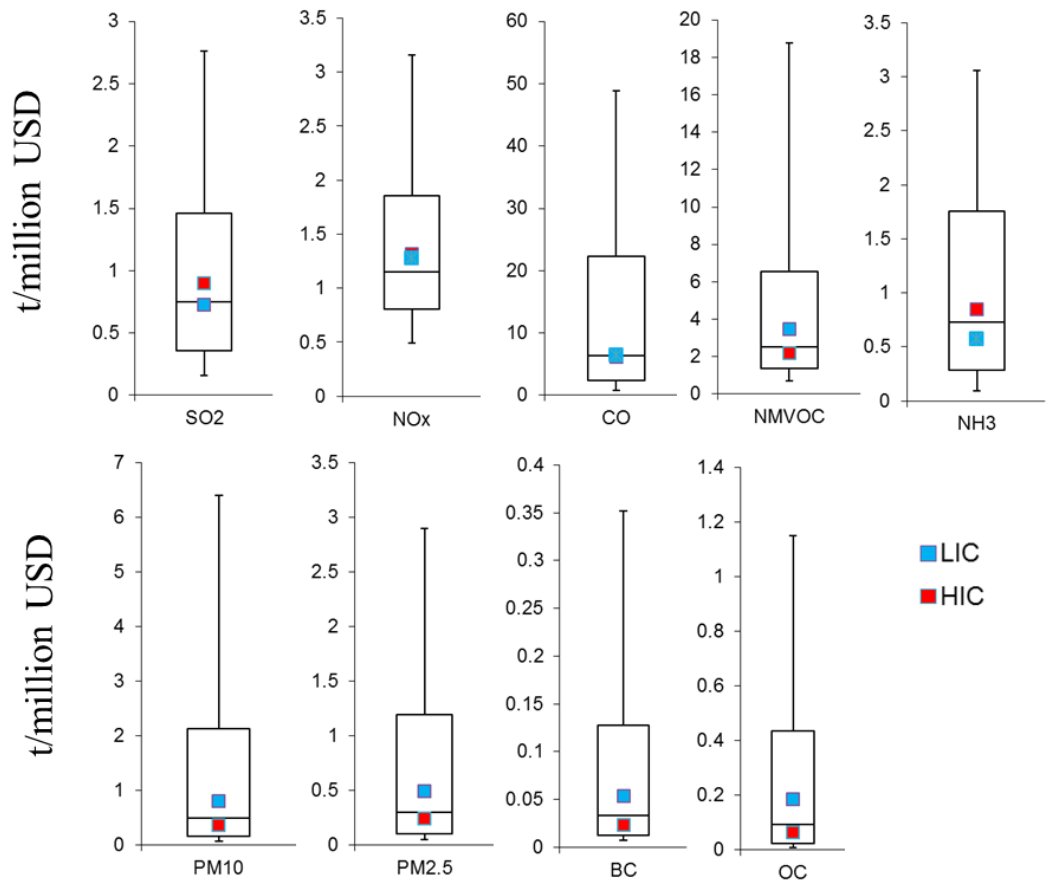

-

=HIC

Figure 9. Pollutant-specific emissions divided by GDP (t million $\mathrm{USD}^{-1}$ ) for the year 2010. Percentiles of emissions per GDP are reported in the box plots (10th, 25th, 50th, 75th, and 90th percentile), while the median of low-income and high-income countries is represented with light blue and red makers, respectively.

sions trends and the consistency of the EDGAR proxy data over that time frame.

\subsection{Gridded emission sector shares}

With the perspective of providing more insights into the composition of the total emissions and source decomposition within a single grid cell, the EDGAR v4.3.2 also provides the emission sector shares at the grid-cell level as NetCDF files at http://edgar.jrc.ec.europa.eu/overview.php? v=432_AP (last access: October 2018). Emission shares of each sector in total emissions are calculated for 2012 for each pollutant $\left(\mathrm{NO}_{x}, \mathrm{CO}, \mathrm{SO}_{2}\right.$, and $\left.\mathrm{PM}_{2.5}\right)$ and for $\mathrm{CO}_{2}$ as a reference proxy for activity (including both the fossil and biogenic components). This information can be used for the analysis of different sector emission shares for urban and rural locations or for different countries, for example, as well as to compare to the sector composition of total column measurements performed by e.g satellites. However, it is important to mention that the assignment of sectorial information per grid cell and the calculation of emission ratios of co-emitted pollutants are subject to high uncertainty, including both the uncertainty about co-emission and the one related to the quality of the spatial allocation in the grid maps. As the total emissions of the different pollutants show different trends over the past, it is expected that these sector shares change with time. The scatter plots shown in Fig. 12 show the trends of emission sector shares over the considered 5-year time step
(2007-2012). In regions with relatively small trends, sectorspecific emission shares can also safely be used for other years. The $1: 1$ line indicates no change between the share of each specific sector and cell between the 2 years; in addition the $\pm 20 \%$ deviation from the $1: 1$ line is reported. Deviations from the $1: 1$ line can be due to large changes in the emissions of specific sectors and/or to a change in the proxy data used for the spatial distribution. It is worth to mention that ratios deviating from 1 can represent a real change in that sector share, but they can also reflect a change in the shares of the other sectors due to their complementarity. The comparison of the 2012 vs. the 2007 sector share pictures is needed to evaluate the stability of the 2012 emission sector shares we provide and the possible need of annual grid maps to track changes in emission sector shares. As shown in Table 1, the energy sector is the one varying the most over a 5 -year time period (from $3.7 \%$ to $7.5 \%$ of the points in the scatter plots of all pollutants vary more than $20 \%$ between 2007 and 2012), being affected by the change in the proxy data (location of point sources) provided by the CARMAv3.0 database (2012) between the considered 2 years (refer to Sect. S3.1 for details about the CARMA database). This result indicates that to have more accurate point source emission estimates (like the ones of the energy sector), annual spatial proxy data would be needed in order to track all the changes happening in that sector (e.g. the opening, closure, or refitting of power plants, switch to a different fuel, change of capacity, etc.). $0.5 \%$ of the $\mathrm{CO}_{2}$ emission shares 

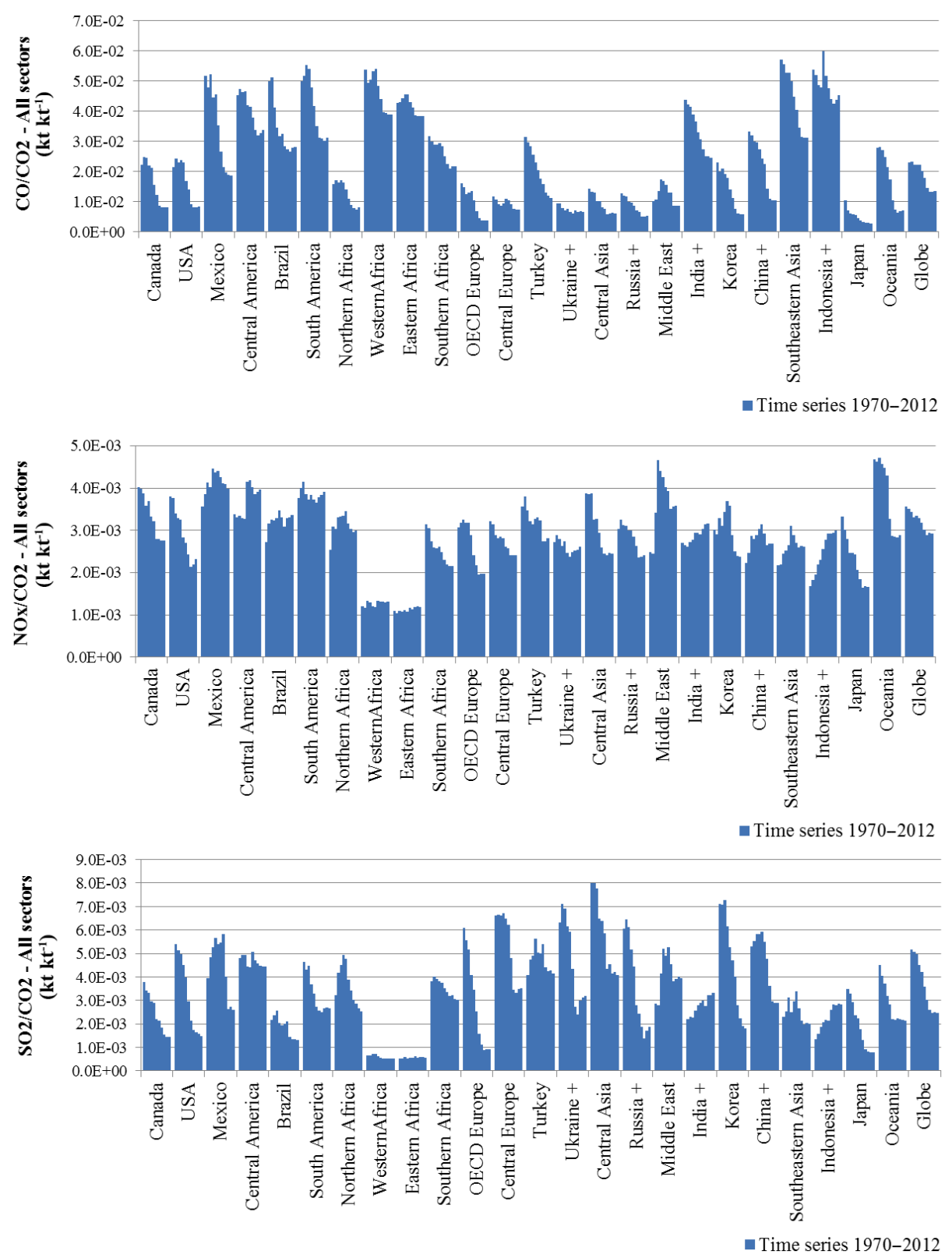

Figure 10. Regional comparison of $\mathrm{CO} / \mathrm{CO}_{2}, \mathrm{NO}_{x} / \mathrm{CO}_{2}$, and $\mathrm{SO}_{2} / \mathrm{CO}_{2}$ emission ratios in 5 year time steps from 1970 to 2012 for all emitting sectors.

from the industrial sector vary more than $20 \%$ between 2007 and 2012. In particular, changes occur in specific regions like Argentina, Indonesia, Iran, etc.; $1.7 \%$ of the cells are outside the $20 \%$ deviation band for the residential sector, particularly affecting Kazakhstan, United Arab Emirates etc. This is due both to changes in population distribution and residential emission changes but also to decreases in the shares of the other sectors. The transport sector shows rather stable spatial shares between 2007 and 2012 (only $1 \%$ of cells out of almost 2 million cells vary more than $20 \%$ ). The agricultural sector shows specific patterns, with higher shares over northern Africa (Algeria, Tunisia, etc.), Cameroon, Ethiopia, South Africa, Zambia, parts of the Middle East and Australia, while decreases in agricultural shares are mainly observed in the sub-Saharan areas, Mongolia, Kazakhstan, and areas of Latin America.

The scatter plots represented in Fig. 12 also show similar patterns as for $\mathrm{CO}_{2}$ for all other sectors, particularly for the energy and industrial sectors. When a single country is characterized by a significant change between 2007 and 2012, this is represented by a curved line in the scatters (e.g. in the $\mathrm{SO}_{2}$ industry scatter plot the lower curved line represents a 

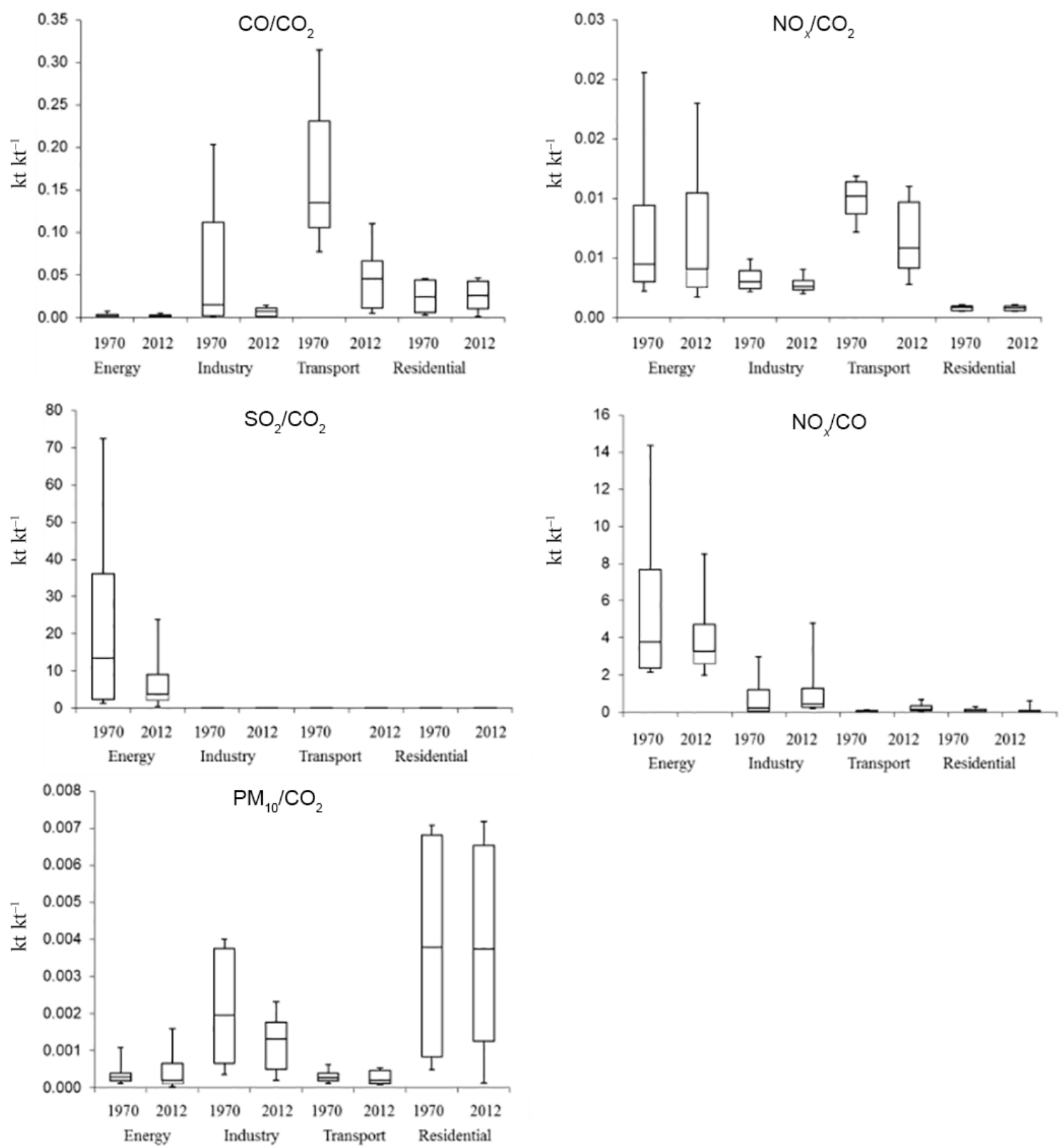

Figure 11. Comparison of 1970 and 2012 global emission ratios of $\mathrm{CO} / \mathrm{CO}_{2}, \mathrm{NO}_{x} / \mathrm{CO}_{2}, \mathrm{SO}_{2} / \mathrm{CO}_{2}, \mathrm{NO}_{x} / \mathrm{CO}$, and $\mathrm{PM}_{10} / \mathrm{CO} 2$ (expressed in $\mathrm{kt} \mathrm{kt}^{-1}$ ) for different sectors. Box plots are calculated, including all world countries, and represent the 10th, 25th, 50th, 75th, and 90th percentiles.

change in Turkey and the upper curve in the $\mathrm{NO}_{x}$ residential scatter reflects an increase in 2012 for Kazakhstan). Here, we do not aim at addressing all the changes of the sector shares observed at the grid-cell level, which already represents a minority of the analyzed points. However, we want to highlight that for some countries, significant differences might happen even from one year to another for specific sectors, so an annual reporting of their emissions should be recommended to track peculiar changes.
Maps in Figs. 13 and 14 represent the relative sector contribution of $\mathrm{SO}_{2}$ and $\mathrm{NO}_{x}$ in 2012, while maps of Figs. S6 and S7 in the Supplement are related to the sector shares of $\mathrm{CO}$ and $\mathrm{PM}_{2.5}$. Considering $\mathrm{SO}_{2}$ and $\mathrm{NO}_{x}$ emission shares, the energy sector is characterized by high emitting point sources in all world regions. On the other hand, the industrial sector is characterized by high emitting point sources over emerging economies and lower shares over the USA and Europe, but also by flaring activities in the North Sea, 

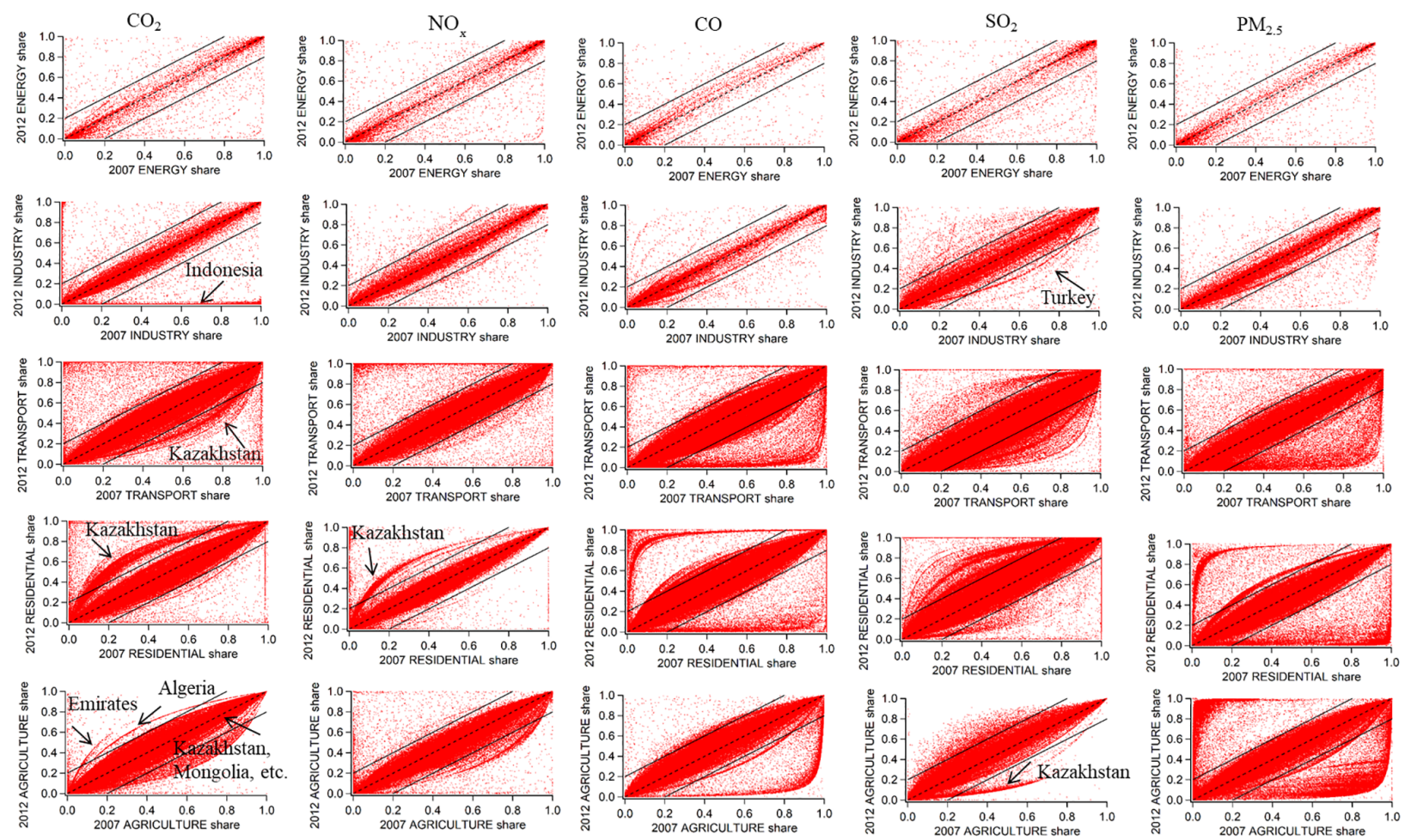

Figure 12. Comparison between the 2012 and 2007 emission shares by sector at the grid-cell level for $\mathrm{CO}_{2}($ reference $\mathrm{gas}), \mathrm{NO}_{x}, \mathrm{CO}, \mathrm{SO}_{2}$, and $\mathrm{PM}_{2.5}$.

Table 1. Fraction of grid cells (represented by each point) outside the $20 \%$ deviation band is reported together with the total number of emitting grid cells (in brackets).

\begin{tabular}{llllll}
\hline & \multicolumn{5}{c}{ Fraction of grid cells with a variation of more than 20\% between 2007 and 2012} \\
\cline { 2 - 5 } & Energy & Industry & Transport & Residential & Agriculture \\
\hline $\mathrm{CO}_{2}$ & $5.9 \%(1.49 \mathrm{E}+4)$ & $0.5 \%(1.45 \mathrm{E}+6)$ & $1.0 \%(1.97 \mathrm{E}+6)$ & $1.7 \%(1.44 \mathrm{E}+6)$ & $0.8 \%(8.50 \mathrm{E}+5)$ \\
$\mathrm{SO}_{2}$ & $7.5 \%(1.49 \mathrm{E}+4)$ & $2.8 \%(1.34 \mathrm{E}+5)$ & $1.9 \%(1.97 \mathrm{E}+6)$ & $3.2 \%(1.44 \mathrm{E}+6)$ & $1.3 \%(6.39 \mathrm{E}+5)$ \\
$\mathrm{NO}_{x}$ & $6.4 \%(1.49 \mathrm{E}+4)$ & $1.4 \%(1.25 \mathrm{E}+5)$ & $0.4 \%(1.97 \mathrm{E}+6)$ & $0.9 \%(1.44 \mathrm{E}+6)$ & $0.6 \%(1.47 \mathrm{E}+6)$ \\
$\mathrm{CO}$ & $3.7 \%(1.49 \mathrm{E}+4)$ & $0.9 \%(1.25 \mathrm{E}+5)$ & $2.0 \%(1.97 \mathrm{E}+6)$ & $3.9 \%(1.44 \mathrm{E}+6)$ & $2.0 \%(6.39 \mathrm{E}+5)$ \\
$\mathrm{PM}_{2.5}$ & $4.5 \%(1.49 \mathrm{E}+4)$ & $0.9 \%(1.39 \mathrm{E}+5)$ & $1.1 \%(1.97 \mathrm{E}+6)$ & $3.9 \%(1.44 \mathrm{E}+6)$ & $3.8 \%(1.47 \mathrm{E}+6)$ \\
\hline
\end{tabular}

Middle East, Persian Gulf, and around the western coast of Africa. $\mathrm{NO}_{x}$ emitted by the transport sector is contributing for more than $50 \%$ of emissions over industrialized areas like the USA, Europe, and Australia, with a $100 \%$ contribution over the sea due to the emissions of international shipping and aviation (this feature is common for all pollutants). The residential sector shows the largest shares over China, Africa, and India (more than $50 \%$ relative contribution) for $\mathrm{SO}_{2}$ (but also for $\mathrm{CO}$ and $\mathrm{PM}_{2.5}$, as shown in Figs. S6 and S7), while lower shares are observed for $\mathrm{NO}_{x}$. The agricultural sector is a dominant source in some areas of northern Africa, Australia, and mainly Latin America (Argentina and Brazil).

\subsection{Hot spots evolution over time}

Figures $15 \mathrm{a}-\mathrm{c}$ and $\mathrm{S} 8 \mathrm{a}-\mathrm{b}$ represent the ratio between the 2007 and 2012 total emissions at the grid-cell level for $\mathrm{CO}_{2}$, $\mathrm{NO}_{x}, \mathrm{CO}, \mathrm{SO}_{2}$, and $\mathrm{PM}_{2.5} . \mathrm{CO}_{2}$ is also shown as reference, since it mainly reflects changes in activity data. The green colour represents a ratio between 0.8 and 1.2 (a ratio of 1 represents no change between 2007 and 2012 emissions at the grid-cell level), the blue colours refer to lower emissions in 2012 compared to 2007, while the yellow and red colours represent higher emissions for the year 2012 compared to 2007. The bubbles represent the top emitting 10000 grid cells at $0.1^{\circ} \times 0.1^{\circ}$ over the whole globe for $\mathrm{CO}_{2}$ and $\mathrm{NO}_{x}$ in 2012 and in 2007, representing more than $94 \%$ of total $\mathrm{CO}_{2}$ emissions. The same cells are then used to pro- 

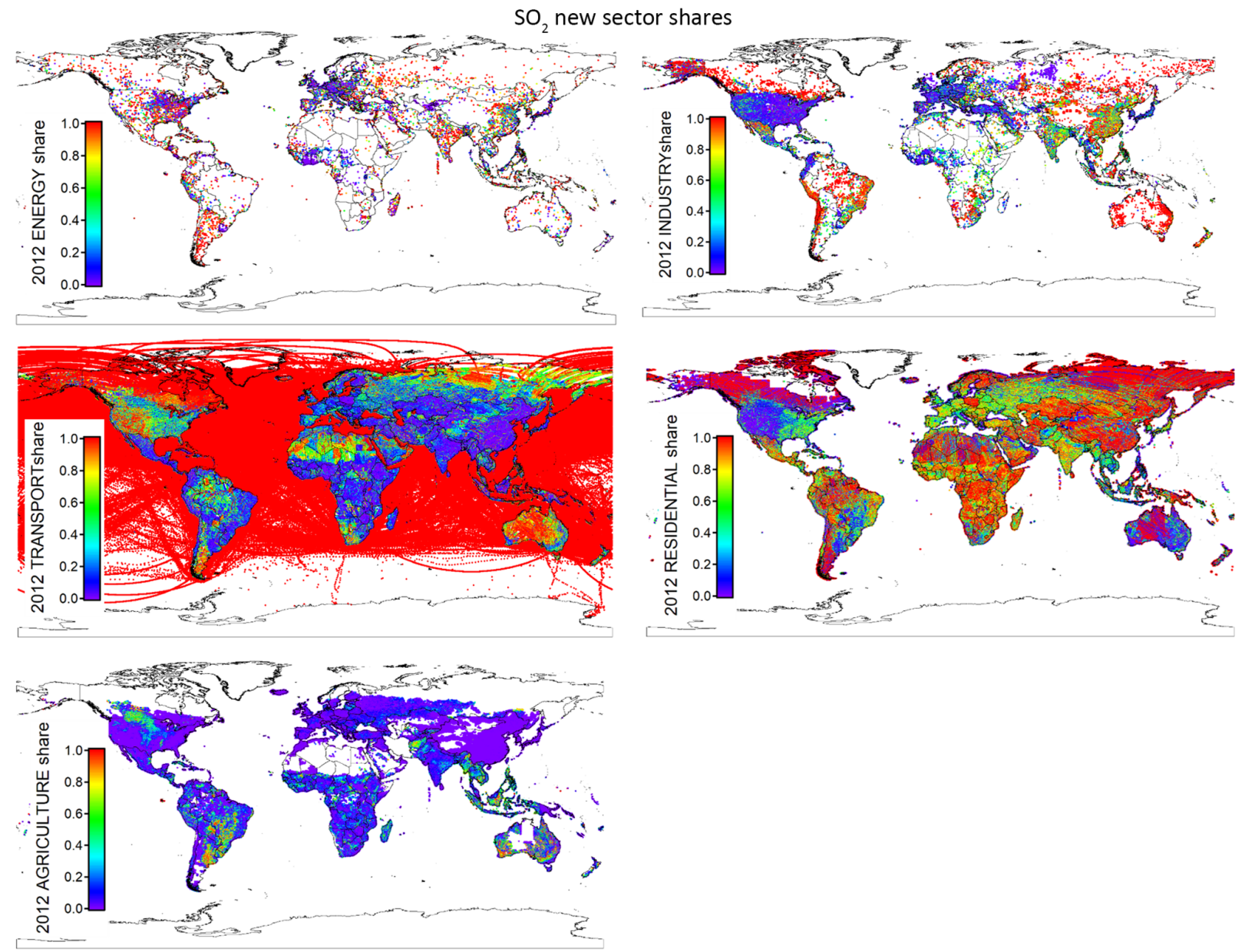

Figure 13. $\mathrm{SO}_{2}$ emission sector shares for the year 2012 at the grid-cell level.

duce the maps for all the other pollutants for comparability reasons, while the size of each bubble is proportional to the magnitude of the 2012 emission for the specific cell and pollutant, therefore the radius of the bubbles cannot be directly compared among all the maps. For $\mathrm{CO}_{2}$ (Fig. 15a), large areas of the world are covered by green colours, indicating no big changes between the 2007 and 2012 emissions. Among all the green cells, the green bubbles represent the top emitting cells in 2012 and/or 2007, which did not change significantly from 2007 . The very big yellow bubbles over China represent large high emitting sources that increased their emissions from 2007 to 2012. On the other hand India is characterized by rather small but red bubbles, which represent growing emitting points. $\mathrm{NO}_{x}$ and $\mathrm{CO}_{2}$ maps are quite similar (Fig. 15a and b), meaning that coherent trends are observed for the two pollutants. However, some differences can be observed over North America, characterized by a decreasing trend in $\mathrm{NO}_{x}$ emissions, mainly from the transport sector that is counterbalanced by a relatively stable fuel consumption (no significant trend is observed for $\mathrm{CO}_{2}$ between 2007 and 2012).
$\mathrm{SO}_{2}$ emissions (Fig. 15c) generally decreased from 2007 to 2012 in industrialized countries (e.g. North America and Europe), which was mainly due to the deployment of lower sulfur content fuels and technologies to clean up the fuels (including deSOx). However, some red hot spots can be found in central and eastern Europe due to the larger deployment of low-grade coal and in Mexico. Shipping tracks along the American coasts and across the Atlantic Ocean are often red, representing increased shipping activity in this area (IEA reports the increase of diesel and heavy residual oils as fuels in this sector by the USA). Quite a few hot spots are observed over the Arabian Peninsula, Iraq, etc., due to the larger deployment of diesel and heavy residual fuel oil for public electricity generation and the use of coal in the industrial sector.

$\mathrm{CO}$ and $\mathrm{PM}_{2.5}$ emission trends (refer to Fig. S8a-b) are mostly stable or decreasing over industrialized regions because of the higher energy efficiency technologies. Strong decreases are observed over Spain and Greece due to the economic recession, consistent with Fig. 15a. On the contrary, emerging economies like India and China are characterized by an increasing trend of $\mathrm{CO}$ and $\mathrm{PM}_{2.5}$ emissions. 

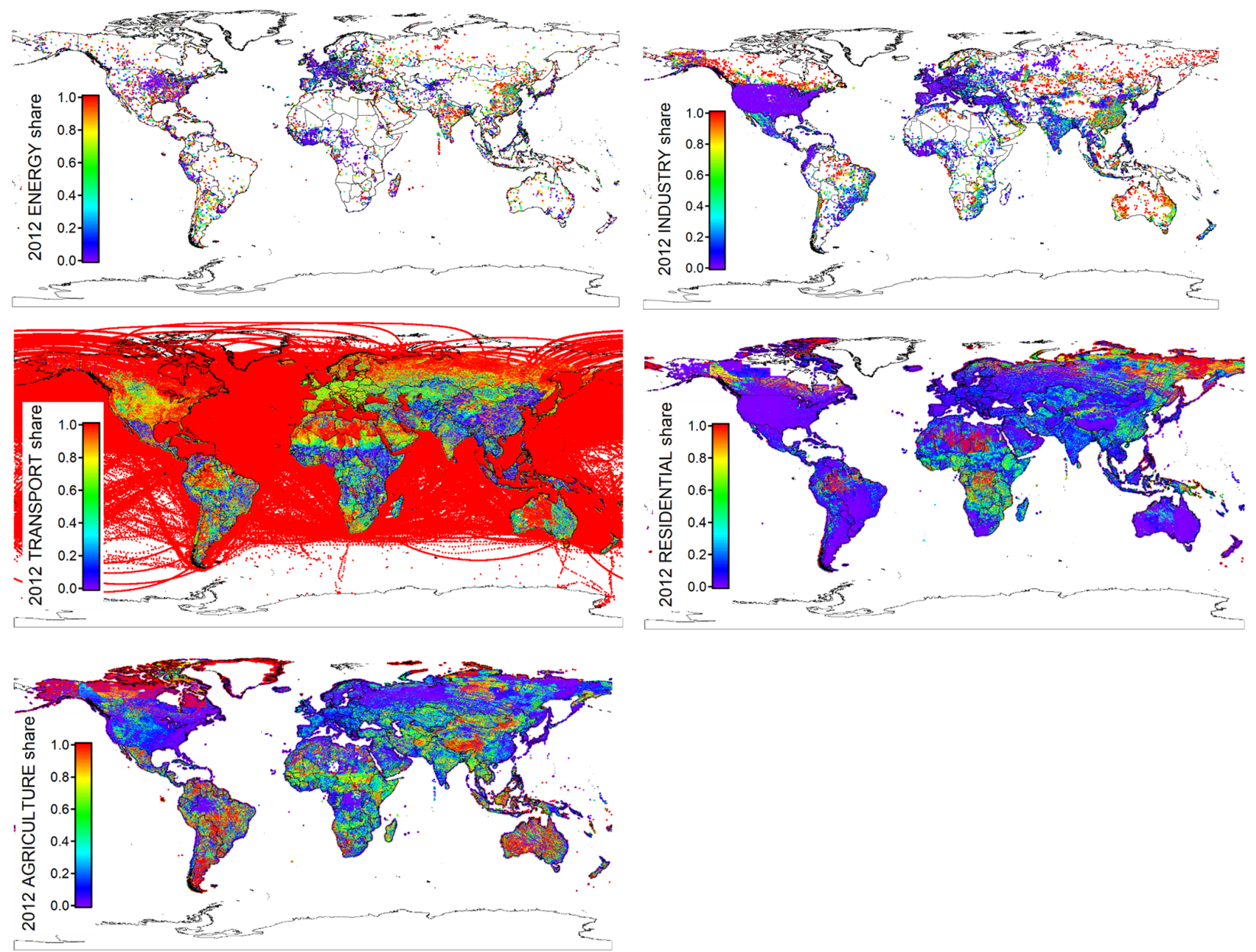

Figure 14. $\mathrm{NO}_{x}$ emission sector shares for the year 2012 at the grid-cell level.

\section{Data availability}

Annual grid maps for all gaseous and particulate air pollutants and sectors covering the years 1970-2012 are available as .txt files (expressed in the unit ton substance per grid cell) and NetCDF files (.nc; expressed in $\mathrm{kg}$ substance $\mathrm{m}^{-2} \mathrm{~s}^{-1}$ ) with $0.1^{\circ} \times 0.1^{\circ}$ spatial resolution in the map gallery at http://edgar.jrc.ec.europa.eu/overview. php?v=432_AP (last access: October 2018). Data are presented online for each source category with annual and monthly global emission grid maps with $0.1^{\circ} \times 0.1^{\circ}$ resolution. They are registered under DOI: https://data.europa.eu/ doi/10.2904/JRC_DATASET_EDGAR (Crippa et al., 2018) and can be freely accessed via the EDGAR website at http:// edgar.jrc.ec.europa.eu/overview.php?v=432_AP (last access: October 2018). In addition, monthly air pollutant grid maps are produced for 2012 and are available per sector and substance. The following DOI is associated with the EDGAR v4.3.2 air pollutant release: https://data.europa.eu/doi/10. 2904/JRC_DATASET_EDGAR (Crippa et al., 2018).

\section{Conclusion and outlook}

This study builds on a previous study that presented EDGAR v4.3.2 results for $\mathrm{CO}_{2}$ and other GHGs (Janssens-Maenhout et al., 2017). In this work, we document the scientific global emission inventory EDGAR v4.3.2 to provide a consistently compiled and comprehensive dataset of anthropogenic emissions of gaseous and particulate air pollutants $\left(\mathrm{SO}_{2}, \mathrm{NO}_{x}\right.$, CO, NMVOC, $\mathrm{NH}_{3}, \mathrm{PM}_{10}, \mathrm{PM}_{2.5}, \mathrm{BC}$, and $\mathrm{OC}$ ) over the time period 1970-2012 (with annual and monthly resolution) and spatially disaggregated grid maps with $0.1^{\circ} \times 0.1^{\circ}$ resolution. A strength of EDGAR v4.3.2 is that the bottom-up emissions calculation methodology is consistently applied for all world countries in a sectorial structure that is also used to compute greenhouse gases by IPCC, allowing for the consistent co-benefit analysis of GHG emission reduction strategies for air pollutants. In addition to the emission time series, we provide emissions per capita and per GDP as well as implied EFs (emissions per unit of energy or product) to allow further analysis of efficiency and comparability between countries. We find that the calculated implied EFs 

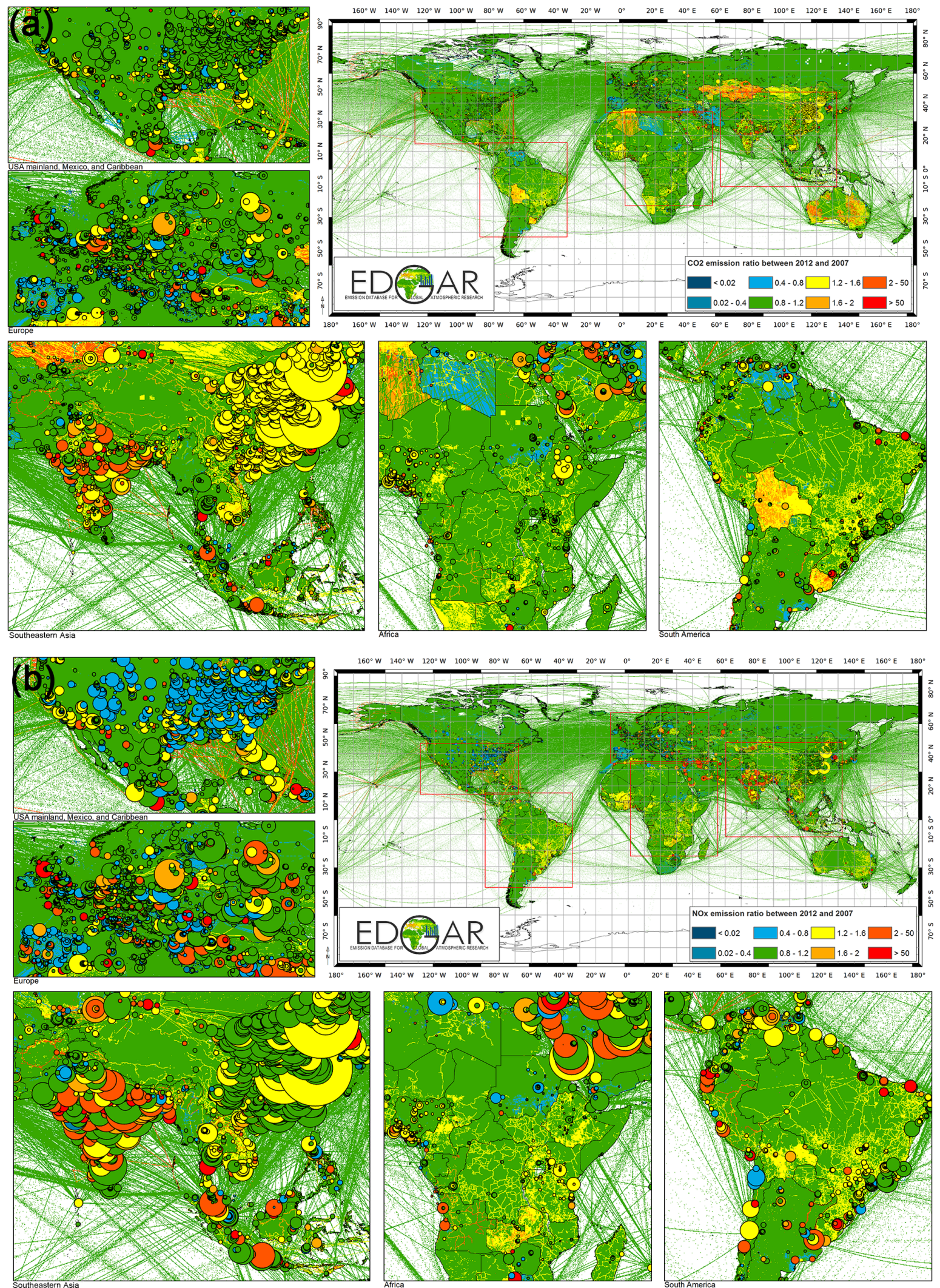

Figure 15. 

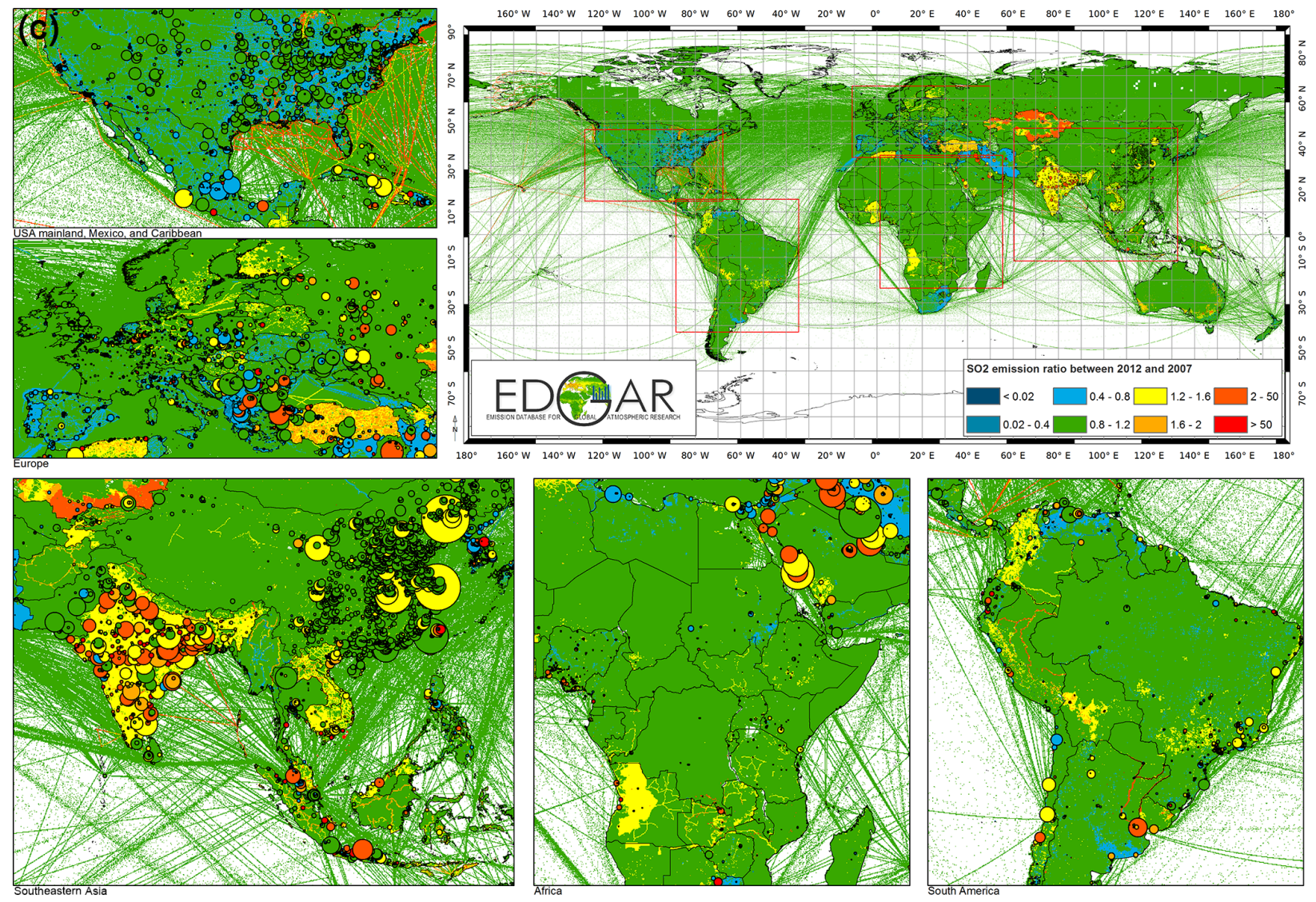

Figure 15. (a) Ratio of total $\mathrm{CO}_{2}$ emissions, which represents a proxy for activity between 2007 and 2012 at the grid-cell level. The coloured bubbles represent the top emitting cells, as described in the text. (b) Ratio of all sectors $\mathrm{NO}_{x}$ emissions between 2012 and 2007 at the gridcell level. The coloured bubbles represent the top emitting cells, as described in the text. (c) Ratio of all sectors $\mathrm{SO}_{2}$ emissions between 2007 and 2012 at the grid-cell level. The coloured bubbles represent the top emitting cells, as described in the text.

are higher for low-income compared to high-income countries, but they were decreasing overall from 1970 to 2012. In addition, we present the emission ratios of co-emitted pollutants, in particular, $\mathrm{CO}, \mathrm{NO}_{x}$, and $\mathrm{SO}_{2}$ to $\mathrm{CO}_{2}$. We hope that the combination of this emission information with atmospheric observations (in situ or space-borne) can further improve our understanding of the emissions and the driving human activities. The analysis of emission hot spots using the gridded emissions identifies a growing amount of high-emitting areas (China, India, the Middle East, and some South American countries) in the world, with important implications for global air quality. In contrast, Europe or the USA shows rather stable or decreasing emissions. To provide information that can help to better constrain emission inventories' estimates with ground-based and satellite measurements, we investigated the emission ratios of $\mathrm{CO} / \mathrm{CO}_{2}$, $\mathrm{NO}_{x} / \mathrm{CO}_{2}, \mathrm{SO}_{2} / \mathrm{CO}_{2}$, and $\mathrm{PM} / \mathrm{CO}_{2}$. Lower emission ratios of each species to $\mathrm{CO}_{2}$ are found in 2012 than in 1970 for most of the sectors due to global development towards clean air technologies; in particular, the $\mathrm{SO}_{2} / \mathrm{CO}_{2}$ emission ratio shows the largest decrease from 1970 to 2012 . We also in- vestigate the sector-specific emission ratios of each pollutant to $\mathrm{CO}_{2}$. The $\mathrm{NO}_{x} / \mathrm{CO}_{2}$ ratios are the highest for the power generation sector, due to the high combustion temperatures producing high levels of $\mathrm{NO}_{x}$ and low $\mathrm{CO}$, while the $\mathrm{PM}_{10} / \mathrm{CO}_{2}$ emission ratio is the largest for the residential sector, which is due to the scarce implementation of abatement measures, lack of strict regulations, low-quality fuels used for household purposes, and often inefficient combustion processes. Finally, the assessment of the stability of sector-specific emission shares at the grid-cell level over time aims at providing insights for the modelling and satellite communities on the sector-disaggregated gridded emissions to be applied at bulk composition of the atmosphere.

\section{The Supplement related to this article is available online at: https://doi.org/10.5194/essd-10-1987-2018- supplement}

Author contributions. MC prepared the manuscript with contributions from GJM and FD, who supervised the scientific content of this publication. All co-authors, in particular the current JRC 
EDGAR Team, helped in developing the EDGARv4.3.2 database, which is described in the current publication. Specifically, ES, MM, MC and GJM worked on the update of activity data, emission factors and technologies, while DG worked on the development of the spatial distribution of the emissions and provided IT support for the EDGAR database.

Competing interests. The authors declare that they have no conflict of interest.

Acknowledgements. The EDGAR database compilation was initiated by JGJO (PBL) and was under the overall responsibility of the Joint Research Centre after 2008. Over the years a number of scientists and technicians have supported the EDGAR - we are grateful for their contributions. Specifically, the EDGAR v4 development profited from the substantial contribution of the authors JAvA, SM, UD, and VP during their affiliation with JRC. The current JRC EDGAR Team further developed the EDGAR v4.3.2 database and produced this publication. The authors are further grateful to the IEA, Karen Treanton, and Roberta Quadrelli for the collaboration and data exchange of the energy-related statistics and to Julian Wilson (JRC) for the thorough review and English proofreading. The authors are further grateful to the IEA, Karen Treanton, and Roberta Quadrelli for the collaboration and data exchange of the energy-related statistics and to Julian Wilson (JRC) for the thorough review and English proofreading.

Edited by: Vinayak Sinha

Reviewed by: four anonymous referees

\section{References}

Anenberg, S. C., Schwartz, J., Vignati, E., Emberson, L., Muller, N. Z., West, J. J., Williams, M., Demkine, V., Hicks, W. K., and Kuylenstierna, J.: Global Air Quality and Health Co-benefits of Mitigating Near-Term Climate Change through Methane and Black Carbon Emission Controls, Environ. Health Persp., 120, 831-839, https://doi.org/10.1289/ehp.1104301, 2012.

Bond, T. C., Streets, D. G., Yarber, K. F., Nelson, S. M., Woo, J.-H., and Klimont, Z.: A technology-based global inventory of black and organic carbon emissions from combustion, J. Geophys. Res.-Atmos., 109, D14203, https://doi.org/10.1029/2003jd003697, 2004.

Bond, T. C., Bhardwaj, E., Dong, R., Jogani, R., Jung, S., Roden, C., Streets, D. G., and Trautmann, N. M.: Historical emissions of black and organic carbon aerosol from energy-related combustion, 1850-2000, Global Biogeochem. Cy. 21, GB2018, https://doi.org/10.1029/2006gb002840, 2007.

Cai, C., Geng, F., Tie, X., Yu, Q., and An, J.: Characteristics and source apportionment of VOCs measured in Shanghai, China, Atmos. Environ., 44, 5005-5014, https://doi.org/10.1016/j.atmosenv.2010.07.059, 2010.

CARMAv3.0: Carbon Monitoring for Action: power plants: data, version v3.0 available at: http://carma.org/plant (last access: April 2018), 2012.
Crippa, M., Janssens-Maenhout, G., Dentener, F., Guizzardi, D., Sindelarova, K., Muntean, M., Van Dingenen, R., and Granier, C.: Forty years of improvements in European air quality: regional policy-industry interactions with global impacts, Atmos. Chem. Phys., 16, 3825-3841, https://doi.org/10.5194/acp-163825-2016, 2016a.

Crippa, M., Janssens-Maenhout, G., Guizzardi, D., and Galmarini, S.: EU Effect: Exporting Emission Regulations through Global Market Economy, J. Environ. Manage., 183, 959-971, https://doi.org/10.1016/j.jenvman.2016.09.068, 2016 b.

Crippa, M., Janssens-Maenhout, G., Guizzardi, D., Van Dingenen, R., and Dentener, F.: Sectorial and regional uncertainty analysis of the contribution of anthropogenic emissions to regional and global $\mathrm{PM}_{2.5}$ health impacts, Atmos. Chem. Phys. Discuss., https://doi.org/10.5194/acp-2017-779, in review, 2017.

Crippa, M., Guizzardi, D., Muntean, M., Schaaf, E., and Janssens-Maenhout, G.: Emissions Database for Global Atmospheric Research, version v4.3.2 part II Air Pollutants, https://doi.org/10.2904/JRC_DATASET_EDGAR, 2018.

Dalsøren, S. B., Eide, M. S., Endresen, Ø., Mjelde, A., Gravir, G., and Isaksen, I. S. A.: Update on emissions and environmental impacts from the international fleet of ships: the contribution from major ship types and ports, Atmos. Chem. Phys., 9, 2171-2194, https://doi.org/10.5194/acp-9-2171-2009, 2009.

D’Angiola, A., Dawidowski, L., D., Gómez, and Osses, M.: On road traffic emissions in a megacity, Atmos. Environ., 44, 483-493, 2010.

Denier van der Gon, H. A. C., Bergström, R., Fountoukis, C., Johansson, C., Pandis, S. N., Simpson, D., and Visschedijk, A. J. H.: Particulate emissions from residential wood combustion in Europe - revised estimates and an evaluation, Atmos. Chem. Phys., 15, 6503-6519, https://doi.org/10.5194/acp15-6503-2015, 2015.

EC-JRC/PBL, European Commission, Joint Research Centre (JRC)/Netherlands Environmental Assessment Agency (PBL): Emission Database for Global Atmospheric Research (EDGAR), release EDGAR version 4.2, available at: http://edgar.jrc.ec. europa.eu/overview.php?v=42 (last access: October 2018), 2011.

EMEP/EEA: Emission Inventory guidebook, European Environment Agency, available at: https://www.eea.europa. eu/publications/emep-eea-guidebook-2013 (last access: April 2018), 2013.

EMEP/EEA: EMEP/EEA air pollutant emission inventory guidebook 2016, European Environment Agency, Copenhagen, 2016.

EPRTR: European Pollutant Transfer Register, database version v4.2, available at: http://prtr.ec.europa.eu/ (last access: October 2018), 2012.

Eyers, C. J., Addleton, D., Atkinson, K., Broomhead, M. J., Christou, R. A., Elliff, T. E., Falk, R., Gee, I. L., Lee, D. S., Marizy, C., Michot, S., Middel, J., Newton, P., Norman, P., Plohr, M., Raper, D. W., and Stanciou, N.: AERO2k Global Aviation Emissions Inventories for 2002 and 2025, QinetiQ Ltd, Farnborough, Hampshire QINETIQ/04/01113, 2005.

FAO: Forestry production and trade, pulpwood, available at: http: //www.fao.org/faostat/en/\#data/FO, last access: October 2016.

FAOSTAT: Statistics Division of the Food Agricultural Organisation (FAO). Live animal numbers, crop production, total nitrogen fertiliser consumption statistics till 2012, 2014, available at: http: //www.fao.org/faostat/en/\#data/QD, last access: October 2016. 
Fioletov, V., McLinden, C. A., Kharol, S. K., Krotkov, N. A., Li, C., Joiner, J., Moran, M. D., Vet, R., Visschedijk, A. J. H., and Denier van der Gon, H. A. C.: Multi-source $\mathrm{SO}_{2}$ emission retrievals and consistency of satellite and surface measurements with reported emissions, Atmos. Chem. Phys., 17, 12597-12616, https://doi.org/10.5194/acp-17-12597-2017, 2017.

Geng, G., Zhang, Q., Martin, R. V., Lin, J., Huo, H., Zheng, B., Wang, S., and He, K.: Impact of spatial proxies on the representation of bottom-up emission inventories: A satellite-based analysis, Atmos. Chem. Phys., 17, 4131-4145, https://doi.org/10.5194/acp-17-4131-2017, 2017.

Granier, C., Bessagnet, B., Bond, T., D’Angiola, A., Denier van der Gon, H., Frost, G., Heil, A., Kaiser, J., Kinne, S., Klimont, Z., Kloster, S., Lamarque, J.-F., Liousse, C., Masui, T., Meleux, F., Mieville, A., Ohara, T., Raut, J.-C., Riahi, K., Schultz, M., Smith, S., Thompson, A., Aardenne, J., Werf, G., and Vuuren, D.: Evolution of anthropogenic and biomass burning emissions of air pollutants at global and regional scales during the 1980-2010 period, Climatic Change, 109, 163-190, https://doi.org/10.1007/s10584-011-0154-1, 2011.

Hoesly, R. M., Smith, S. J., Feng, L., Klimont, Z., JanssensMaenhout, G., Pitkanen, T., Seibert, J. J., Vu, L., Andres, R. J., Bolt, R. M., Bond, T. C., Dawidowski, L., Kholod, N., Kurokawa, J.-I., Li, M., Liu, L., Lu, Z., Moura, M. C. P., O'Rourke, P. R., and Zhang, Q.: Historical (1750-2014) anthropogenic emissions of reactive gases and aerosols from the Community Emissions Data System (CEDS), Geosci. Model Dev., 11, 369-408, https://doi.org/10.5194/gmd-11-369-2018, 2018.

Höglund-Isaksson, L: Bottom-up simulations of methane and ethane emissions from global oil and gas systems 401980 to 2012, Environ. Res. Lett., 12, 024007, https://doi.org/10.1088/1748-9326/aa583e, 2017.

HTAP, UNECE: Hemispheric Transport of Air Pollution 2010: Part A: Ozone and Particulate Matter, Air Pollution Studies No. 17, edited by: Dentener, F., Keating, T., and Akimoto, H.,ECE/EN.Air/100, ISSN 1014-4625, ISBN 978-92-1-1170436, 2010.

Huang, G., Brook, R., Crippa, M., Janssens-Maenhout, G., Schieberle, C., Dore, C., Guizzardi, D., Muntean, M., Schaaf, E., and Friedrich, R.: Speciation of anthropogenic emissions of non-methane volatile organic compounds: a global gridded data set for 1970-2012, Atmos. Chem. Phys., 17, 7683-7701, https://doi.org/10.5194/acp-17-7683-2017, 2017.

Huang, G., Schieberle, C., and Friedrich, R.: Mapping and integration of temporal profiles in the EDGAR system, JRC report, 2018.

IEA: Energy Statistics of OECD and Non-OECD Countries, Online data service, available at: http://data.iea.org (last accessL April 2018), 2014, 2017.

IMF/WEO: World Economic Outlook Update January 2017, International Monetary Fund, 2017.

IPCC: Revised 1996 IPCC Guidelines for National Greenhouse Gas Inventories IPCC/OECD/ IEA, Paris, 1996.

IPCC: 2006 IPCC Guidelines for National Greenhouse Gas Inventories, edited by: Eggleston, S., Buendia, L., Miwa, K., Ngara, T., and Tanabe, K., IPCC-TSU NGGIP, IGES, Hayama, Japan, available at: www.ipcc-nggip.iges.or.jp/public/2006gl/ index.html (last access: April 2018), 2006.
IPCC: Intergovernmental Panel on Climate Change, Fifth Assessment Report, available at: http://www.ipcc.ch/ (last access: April 2018), 2013.

Janssens-Maenhout, G., Crippa, M., Guizzardi, D., Dentener, F., Muntean, M., Pouliot, G., Keating, T., Zhang, Q., Kurokawa, J., Wankmüller, R., Denier van der Gon, H., Kuenen, J. J. P., Klimont, Z., Frost, G., Darras, S., Koffi, B., and Li, M.: HTAP_v2.2: a mosaic of regional and global emission grid maps for 2008 and 2010 to study hemispheric transport of air pollution, Atmos. Chem. Phys., 15, 11411-11432, https://doi.org/10.5194/acp-15-11411-2015, 2015.

Janssens-Maenhout, G., Crippa, M., Guizzardi, D., Muntean, M., Schaaf, E., Dentener, F., Bergamaschi, P., Pagliari, V., Olivier, J. G. J., Peters, J. A. H. W., van Aardenne, J. A., Monni, S., Doering, U., and Petrescu, A. M. R.: EDGAR v4.3.2 Global Atlas of the three major Greenhouse Gas Emissions for the period 1970-2012, Earth Syst. Sci. Data Discuss., https://doi.org/10.5194/essd-2017-79, 2017.

Klimont, Z., Smith, S. J., and Cofala, J.: The last decade of global anthropogenic sulfur dioxide: 2000-2011 emissions, Environ. Res. Lett., 8, 014003, https://doi.org/10.1088/17489326/8/1/014003, 2013.

Klimont, Z., Kupiainen, K., Heyes, C., Purohit, P., Cofala, J., Rafaj, P., Borken-Kleefeld, J., and Schöpp, W.: Global anthropogenic emissions of particulate matter including black carbon, Atmos. Chem. Phys., 17, 8681-8723, https://doi.org/10.5194/acp-178681-2017, 2017.

Konovalov, I. B., Berezin, E. V., Ciais, P., Broquet, G., Zhuravlev, R. V., and Janssens-Maenhout, G.: Estimation of fossil-fuel $\mathrm{CO}_{2}$ emissions using satellite measurements of "proxy" species, Atmos. Chem. Phys., 16, 13509-13540, https://doi.org/10.5194/acp-16-13509-2016, 2016.

Lamarque, J.-F., Bond, T. C., Eyring, V., Granier, C., Heil, A., Klimont, Z., Lee, D., Liousse, C., Mieville, A., Owen, B., Schultz, M. G., Shindell, D., Smith, S. J., Stehfest, E., Van Aardenne, J., Cooper, O. R., Kainuma, M., Mahowald, N., McConnell, J. R., Naik, V., Riahi, K., and van Vuuren, D. P.: Historical (1850-2000) gridded anthropogenic and biomass burning emissions of reactive gases and aerosols: methodology and application, Atmos. Chem. Phys., 10, 7017-7039, https://doi.org/10.5194/acp-10-7017-2010, 2010.

Liu, Y., Shao, M., Fu, L., Lu, S., Zeng, L., and Tang, D.: Source profiles of volatile organic compounds (VOCs) measured in China: Part I, Atmos. Environ., 42, 6247-6260, https://doi.org/10.1016/j.atmosenv.2008.01.070, 2008.

Maas, R. and Grennfelt, P.: Towards Cleaner Air, Scientific Assessment Report 2016, EMEP Steering Body and Working Group on Effects of the Convention on Long-Range Transboundary Air Pollution, Oslo, 2016.

Monks, P. S., Granier, C., Fuzzi, S., Stohl, A., Williams, M. L., Akimoto, H., Amann, M., Baklanov, A., Baltensperger, U., Bey, I., Blake, N., Blake, R. S., Carslaw, K., Cooper, O. R., Dentener, F., Fowler, D., Fragkou, E., Frost, G. J., Generoso, S., Ginoux, P., Grewe, V., Guenther, A., Hansson, H. C., Henne, S., Hjorth, J., Hofzumahaus, A., Huntrieser, H., Isaksen, I. S. A., Jenkin, M. E., Kaiser, J., Kanakidou, M., Klimont, Z., Kulmala, M., Laj, P., Lawrence, M. G., Lee, J. D., Liousse, C., Maione, M., McFiggans, G., Metzger, A., Mieville, A., Moussiopoulos, N., Orlando, J. J., O’Dowd, C. D., Palmer, P. I., Parrish, D. D., Petzold, A., 
Platt, U., Pöschl, U., Prévôt, A. S. H., Reeves, C. E., Reimann, S., Rudich, Y., Sellegri, K., Steinbrecher, R., Simpson, D., ten Brink, H., Theloke, J., van der Werf, G. R., Vautard, R., Vestreng, V., Vlachokostas, C., and von Glasow, R.: Atmospheric composition change - global and regional air quality, Atmos. Environ., 43, 5268-5350, https://doi.org/10.1016/j.atmosenv.2009.08.021, 2009.

Muntean, M., Janssens-Maenhout, G., Song, Giang, A., Selin, N.; Zhong, H., Zhao, Y., Olivier, J., Guizzardi, D., Crippa, M., Schaaf, E., and Dentener, F.: Evaluating EDGARv4.tox2 speciated mercury emissions ex-post scenarios and their impacts on modelled global and regional wet deposition patterns, Atmos. Environ., 184, 56-68, https://doi.org/10.1016/j.atmosenv.2018.04.017, 2018.

Nassar, R., Hill, T. G., McLinden, C. A., Wunch, D., Jones, D. B. A., and Crisp, D.: Quantifying $\mathrm{CO}_{2}$ Emissions From Individual Power Plants From Space, Geophys. Res. Lett., 44, 10045010053, https://doi.org/10.1002/2017gl074702, 2017.

Salway, A. G., Murrells, T. P., Milne, R., and Ellis, S.: UK Greenhouse Gas Inventory,1990 to 2000 Annual Report for submission under the Framework Convention on Climate Change, AEAT/R/ENV/1000, naei00/ipcc/report/final/ghg_fccc1, Appendix 3, 2002.

Schifter, I., Díaz, L., Múgica, V., and López-Salinas, E.: Fuel-based motor vehicle emission inventory for the metropolitan area of Mexico City, Atmos. Environ., 39, 931-940, 2005.

Schultz, M. G., Backman, L., Balkanski, Y., Bjoerndalsaeter, S., Brand, R., Burrows, J. P., Dalsoeren, S., de Vasconcelos, M., Grodtmann, B., and Hauglustaine, D. A.: REanalysis of the TROpospheric chemical composition over the past 40 years (RETRO) - A long-term global modeling study of tropospheric chemistry, available at: http://retro-archive.iek. fz-juelich.de/data/documents/reports (last access: January 2017), 2007

Seinfeld, J. H. and Pandis, S. N.: Atmospheric Chemistry and Physics: From Air Pollution to Climate Change, 2nd Edn., John Wiley \& Sons, Inc., New York, 2006.

Silva, S. and Arellano, A.: Characterizing Regional-Scale Combustion Using Satellite Retrievals of $\mathrm{CO}, \mathrm{NO}_{2}$ and $\mathrm{CO}_{2}$, Remote Sens.-Basel, 9, 744, https://doi.org/10.3390/rs9070744, 2017.

Streets, D. G., Canty, T., Carmichael, G. R., de Foy, B., Dickerson, R. R., Duncan, B. N., Edwards, D. P., Haynes, J. A., Henze, D. K., Houyoux, M. R., Jacob, D. J., Krotkov, N. A., Lamsal, L. N., Liu, Y., Lu, Z., Martin, R. V., Pfister, G. G., Pinder, R. W., Salawitch, R. J., and Wecht, K. J.: Emissions estimation from satellite retrievals: A review of current capability, Atmos. Environ. 77, 1011-1042, https://doi.org/10.1016/j.atmosenv.2013.05.051, 2013.
UNEP/WMO: Integrated Assessment of Black Carbon and Tropospheric Ozone, ISO 14 001: 2004, UNON/Publishing Services Section, Nairobi, 2011.

UNFCCC, National Inventory Report, submissions of the greenhouse gas inventories for Annex I countries, available at: http://unfccc.int/national_reports/annex_i_ghg_inventories/ national_inventories_submissions/items/7383.php (last access: April 2018), 2014.

UN STATS: Industrial Commodity Production Statistics 19702013, UN Statistics Division, available at: http://unstats.un.org/ unsd/industry/publications.asp (last access: April 2018), 2014.

US EPA: Global Anthropogenic Air Pollutant Emissions: 19902030, EPA report, 2014.

USGS: US Geological Survey Minerals Yearbook, US Geological Survey, Reston, Virginia, available at: http://mninerals.usgs.gov/ minerals/pubs/commodity (last access: April 2018), 2014.

Van Dingenen, R., Dentener, F. J., Raes, F., Krol, M. C., Emberson, L., and Cofala, J.: The global impact of ozone on agricultural crop yields under current and future air quality legislation, Atmos. Environ., 43, 604-618, https://doi.org/10.1016/j.atmosenv.2008.10.033, 2009.

Wang, K. C., Dickinson, R. E., Su, L., and Trenberth, K. E.: Contrasting trends of mass and optical properties of aerosols over the Northern Hemisphere from 1992 to 2011, Atmos. Chem. Phys., 12, 9387-9398, https://doi.org/10.5194/acp-129387-2012, 2012.

Wei, W., Wang, S., Hao, J., and Cheng, S.: Trends of chemical speciation profiles of anthropogenic volatile organic compounds emissions in China, 2005-2020, Front. Environ. Sci. Eng., 8, 1-15, https://doi.org/10.1007/s11783-012-0461-4, 2012.

WHO: Ambient air pollution: a global assessment of exposure and burden of disease, Geneva, World Health Organization, 2016.

Zhao, Y., Nielsen, C. P., McElroy, M. B., Zhang, L., and Zhang, J.: CO emissions in China: Uncertainties and implications of improved energy efficiency and emission control, Atmos. Environ. 49, 103-113, https://doi.org/10.1016/j.atmosenv.2011.12.015, 2012. 